\title{
Non-coding RNAs in lung cancer
}

\author{
Biagio Ricciuti ${ }^{1}$, Carmen Mecca ${ }^{2}$, Lucio Crinò ${ }^{1}$, Sara Baglivo ${ }^{1}$, Matteo Cenci $^{1}$ and \\ Giulio Metro ${ }^{1}$ \\ ${ }^{1}$ Medical Oncology, Santa Maria della Misericordia Hospital, Azienda Ospedaliera di Perugia, Perugia, Italy \\ 2 University of Perugia, Perugia, Italy
}

Correspondence to: Biagio Ricciuti, email: biagio.ricciuti@gmail.com

Keywords: non-coding RNAs, lung cancer, targeted therapy, biomarkers

Received: October 15,2014 Accepted: November 15, $2014 \quad$ Published: November 15, 2014

This is an open-access article distributed under the terms of the Creative Commons Attribution License, which permits unrestricted use, distribution, and reproduction in any medium, provided the original author and source are credited.

ABSTRACT

The discovery that protein-coding genes represent less than $2 \%$ of all human genome, and the evidence that more than $90 \%$ of it is actively transcribed, changed the classical point of view of the central dogma of molecular biology, which was always based on the assumption that RNA functions mainly as an intermediate bridge between DNA sequences and protein synthesis machinery. Accumulating data indicates that non-coding RNAs are involved in different physiological processes, providing for the maintenance of cellular homeostasis. They are important regulators of gene expression, cellular differentiation, proliferation, migration, apoptosis, and stem cell maintenance. Alterations and disruptions of their expression or activity have increasingly been associated with pathological changes of cancer cells, this evidence and the prospect of using these molecules as diagnostic markers and therapeutic targets, make currently non-coding RNAs among the most relevant molecules in cancer research. In this paper we will provide an overview of non-coding RNA function and disruption in lung cancer biology, also focusing on their potential as diagnostic, prognostic and predictive biomarkers.

\section{INTRODUCTION}

Non-coding RNAs (ncRNAs) represent a novel class of RNA molecules fulfilling many basic regulatory functions in Eukaryotes, and whose dysregulation has been reported in a wide spectrum of human diseases, including cancer.

The discovery that the human genome encodes only $\sim 20,000$ protein-coding genes, representing less than $2 \%$ of the total genome sequence, and the demonstration that at least $90 \%$ of the genome is actively transcribed, suggest that most of the transcriptome is constituted by non-coding RNA [1-4]. These findings have been possible because of the development of tiling resolution genomic microarrays and whole genome and transcriptome sequencing technologies (ENCODE project) [4].

To date, non-coding RNAs primarily include: small non coding RNAs, such as transfer RNAs (tRNAs), ribosomal RNAs (rRNAs), small nucleolar RNAs (snoRNAs), microRNAs (miRNAs), small interfering RNAs (siRNA), PIWI-interacting RNAs (piRNA), antisense RNAs, promoter-associated RNAs (PARs) and different types of long non coding RNAs (Table 1).

It is clear today that these kinds of molecules operate not only as gene expression and splicing regulators, but also as epigenetic controllers and guides for cromatine modifying complexes $[1,5]$.

Within this class, miRNA, siRNA, piRNAS, and IncRNAs have been recently studied, and many of their functions are well defined; considering the different activities they perform, it is not surprising that their deregulation may be involved in various human diseases including different types of cancer such as lung, breast, colon, liver and prostate [4].

Thus it seems extremely important to consider all the possible applications of these ncRNAs in oncology, as markers of disease and possible therapeutic targets.

Lung cancer is the leading cause of cancer-related deaths worldwide in both men and women, representing $25 \%$ of all cancer related deaths. Among lung cancers, $80 \%$ are classified as non-small cell lung cancer (NSCLC) and $20 \%$ as small cell lung cancer (SCLC) [6]. Although advances in diagnostic techniques and treatments have resulted in an increased survival rate and knowledge of 


\section{Table 1: Main classes of human non-coding RNA}

\begin{tabular}{|c|c|}
\hline $\begin{array}{l}\text { 1. Small non-coding RNAs } \\
\text { (<200 nt.) }\end{array}$ & \\
\hline Transfer RNAs (tRNA) & Short-chain RNA molecules involved in aminoacids transfer for protein synthesis [7]. \\
\hline $\begin{array}{l}\text { Ribosomal 5S and 5.8S RNA } \\
\text { (rRNA) }\end{array}$ & RNA component of ribosomal subunit involved in protein translation [8-9] \\
\hline MicroRNAs (miRNA) & $\begin{array}{c}\text { Class of small non-coding RNAs that targets protein-coding mRNAs at the post-transcriptional } \\
\text { level (18-22 nt.) [10-11]. }\end{array}$ \\
\hline $\begin{array}{l}\text { Small interfering RNAs } \\
\text { (siRNA) }\end{array}$ & $\begin{array}{l}\text { Post-transcriptional gene silencing RNA-mechanism that involves the degradation of messenger } \\
\qquad R N A \text { in a highly sequence-specific manner }(21-22 \text { nt.) }\end{array}$ \\
\hline $\begin{array}{l}\text { PIWI-interacting RNAs } \\
\text { (piRNA) }\end{array}$ & $\begin{array}{l}\text { Small endogenous non-coding } R N A \text { s that form the piRNA-induced silencing complex (piRISC) in } \\
\text { germline development, involved in the regulation of transposons stability and stem-like epigenetic } \\
\text { state of cancer cells (26-31 nt.) [13-14] }\end{array}$ \\
\hline $\begin{array}{l}\text { Small nuceolar RNAs } \\
\text { (snoRNA) }\end{array}$ & $\begin{array}{c}R N A \text { molecules involved in modification and processing of other RNAs, especially } r R N A s, t R N A s \text { and } \\
\text { snRNAs mainly by site-specific methylation and pseudouridylation [15-17] }\end{array}$ \\
\hline $\begin{array}{l}\text { MicroRNA-offset RNAs } \\
\text { (moRNA) }\end{array}$ & $\begin{array}{l}\text { RNA derived from pre-microRNA with expression levels unrelated to those of the associated } \\
\text { microRNAs }(20 \mathrm{nt} .)[18]\end{array}$ \\
\hline $\begin{array}{l}\text { Promoter-associated short } \\
\text { RNAs (PASRs) }\end{array}$ & $\begin{array}{c}\text { Less than } 200 \text { nt. trascripts that may regulate gene expression through the interaction with genes } \\
\text { promoter sites [19] }\end{array}$ \\
\hline Small nuclear RNAs & $\begin{array}{l}\text { Non-coding RNA molecules involved in pre- } m R N A \text { splicing, and regulation of transcription factors } \\
{[20]}\end{array}$ \\
\hline $\begin{array}{l}\text { Transcription initiation RNAs } \\
\text { (tiRNAs) }\end{array}$ & $\begin{array}{c}18 \text { nucleotides small } R N A \text { conserved from insects to mammals involved involved in transcription } \\
\text { regulation }[25-26]\end{array}$ \\
\hline \multicolumn{2}{|l|}{$\begin{array}{l}\text { 2. Long non-coding RNAs } \\
\text { (>200 nt.) }\end{array}$} \\
\hline $\begin{array}{l}\text { Long non-coding RNAs } \\
\text { (lncRNA) }\end{array}$ & $\begin{array}{c}\text { Polyadenylated } R N A \text { s greater than } 200 \text { nucleotides in length that regulate gene expression } \\
\text { through epigenetic regulation, splicing, imprinting, transcriptional regulation and intracellular } \\
\text { transport }(>200 \mathrm{nt} .)[21]\end{array}$ \\
\hline Antisense RNAs & $\begin{array}{c}\text { Single stranded } R N A \text { complementary to transcribed } m R N A s, \text { involved in binding and blocking the } \\
\text { translation process of the } m R N A \text { target }[22]\end{array}$ \\
\hline $\begin{array}{l}\text { Promoter associated long } \\
\text { RNAs (PARs) }\end{array}$ & $\begin{array}{c}\text { Longer than } 200 \mathrm{nt} \text { trascripts that may regulate gene expression through the interaction with genes } \\
\text { promoter sites [19] }\end{array}$ \\
\hline $\begin{array}{l}\text { Transcribed ultraconserved } \\
\text { regions (T-UCR) }\end{array}$ & $\begin{array}{l}\text { Highly conserved genomic elements involved in the maintenance of splicing factors expression levels } \\
\text { and gene expression regulation [23] }\end{array}$ \\
\hline Pseudogenes & $\begin{array}{l}\text { Non-functional sequences of DNA originally derived from functional genes but with mutations or } \\
\text { premature stop codons that avoid their expression. Involved in regulation of gene expression and } \\
\text { recombination [24] }\end{array}$ \\
\hline $\begin{array}{l}\text { Telomere-associated } \\
\text { ncRNAs (TERRAs) }\end{array}$ & $\begin{array}{c}\text { Negative regulators of telomere length through inhibition of telomerase and involved in telomere } \\
\text { associated diseases including many cancers [27] }\end{array}$ \\
\hline
\end{tabular}


lung cancer biology has also improved, the prognosis remains poor with a 5-year worldwide survival rate of less than $15 \%$ [6]. Current research focuses especially on genomic and epigenomic alterations of protein-coding genes that may be predictive of greater or lesser response to anticancer treatments. Without doubt, the discovery of specific genetic alterations such as EGFR mutations, ALK and ROS1 rearrangements, has enormously improved the outcome of patients harboring this specific kind of modification, mainly because of the development of biological target therapies. In this context, the evidence that specific genetic mutations are related to distinct pathological and clinical features has paved the way to the era of personalized therapy [28-30].

If on one hand this has represented a significant change in the management of these patients, on the other hand the recent advances in our knowledge of non-small cell lung cancer pathobiology and genetic assessment requires us to consider other aspects as well, in particular those concerning the finest mechanisms of gene expression and regulation. Moreover, if we consider that most of the efforts made to date in lung cancer research focused on $2 \%$ of the entire genome we can easily understand how much more efforts are required and how important is to investigate the non-coding genome universe.

\section{MicroRNAs and lung cancer}

MicroRNA are a class of 18-25 nucleotide long, evolutionarily conserved, endogenous, single stranded small non-coding RNAs, that target protein-coding mRNAs at the post-transcriptional level, binding to the 3'-untranslated regions (3' UTRs) of mRNAs, which results in target mRNA degradation or translational inhibition [10, 31].

Actually, it is believed that miRNA genes account for only about $1-2 \%$ of the human genome, nevertheless they control the activity of approximately $50 \%$ of all protein-coding genes [31-33]. In this paragraph we will explore the advancement in human miRNA biology, function and its involvement in lung cancer.

\section{MircoRNA biogenesis and function}

In recent years, much evidence has led to a classification of miRNAs into three main types: intergenic miRNA, coding-intronic miRNA and coding-exonic miRNA [34].

Intergenic miRNAs are transcribed by RNA polymerase II or III and produce an intermediate primary transcript (pri-miRNA); only pri-miRNAs with an appropriate stem length, a flexible terminal loop $\geq$ $10 \mathrm{bp}$ and the capability of producing 5' and 3' singlestranded RNA overhangs can be converted into mature and functional miRNA [35-37]. Then, pri-miRNAs undergo a nuclear cleavage by a multiprotein complex termed microprocessor which includes the RNase III endonuclease Drosha and the double-stranded RNAbinding protein DiGeorge syndrome critical region gene 8 (DGCR8), also named Pasha in invertebrates [37-38]. In particular, data suggests that DGCR8 recognizes the primiRNA through the ssRNA-dsRNA junction at the hairpin base and directs Drosha to a specific cleavage site; after this process, RNase III endonuclease Drosha releases a 6070 bp miRNA precursor called pre-miRNA [37, 39-40].

Otherwise, miRNAs derived from the intronic regions of protein coding genes are trascribed by RNA polymerase II, the miRNA sequence is excised from the pre-mRNA by spliceosomal complex or the microprocessor and liberate a mirtron or a pre-miRNA. These lariats are debranched and refolded into the typical stem-loop structure of pre-miRNAs, and then enter the classical pathway. Alternatively, a primary miRNA (pri-miRNA) is released and undergoes microprocessor cleavage to generate pre-miRNA $[37,41]$.

Subsequently pre-miRNAs are transported to cytoplasm by the RAN GTP-dependent transporter exportin 5; in the cytoplasm, pre-miRNAs are first cleaved by RNase III Dicer into a 22 nucleotide long miRNA duplex, and immediately separated by helicase into a passenger strand, which undergoes a degradation process, and a guide strand. More specifically, the guide strand, which results in 18-25 nucleotide long mature miRNA duplex, becomes part of the miRNA-induced silencing complex (miRISC) that also includes the human immunodeficiency virus transactivating response RNA binding protein (TRBP) and the Protein Kinase R-activating protein (PACT) [37, 42-44].

Also worth mentioning is the Dicer-independent pre-miRNA processing model, based on Argonaute 2 protein (Ago2) and proposed by Cifuentes [45]. Ago2 possesses both a Piwi and PAZ domain with endonuclease activity that cleaves the passenger strand of the precursor 10 nucleotides upstream the guide strand 5'; this cleavage lets the nucleotides near the cleavage sites, that are no longer protected by Ago 2 binding, to subsequently undergo polyuridylation and nuclease-mediated trimming to achieve mature miRNA [37, 45]. Ago2 is also involved in a different Ago2-dependent pre-miRNA processing path based on the aggregation of Dicer, TRBP and Ago2 in a multimeric complex. Ago2 cleaves a single-strand of the pre-miRNA generating a nicked hairpin structure denominated "Ago2-cleaved precursor miRNA." This precursor works as a substrate for consecutive Dicer cleavage to generate the double stranded miRNA duplex [45-48]. Once activated, the RISC complex binds the mRNA target via a base pairing mechanism between the miRNA guide and the 3'UTR of the target [49]. Should they be extensively base-paired, target mRNA is cleaved by Ago 2 and subsequently deadenylated by a protein complex which includes Pop2, Ccr4 and Not1. At this 
point mRNA can be degraded from 3' to 5' by the exosome complex or from 5' to 3' by the Xrn 1p exonucleases after undergoing a decapping process by Dcp enzymes. The mechanism just described is known as Slicer-Dependent Silencing [50-51]. But base-pairing between the miRNA guide and mRNA target is limited, and gives rise to a lump in the RNA duplex which does not allow Ago2 mRNA cleavage and results in the Slicer-independent silencing path which is directly miRNA mediated and consists of mRNA accelerating deadenylation and decapping processes, translation repression, spatial separation of translation components and mRNA sequestration into cytoplasmic foci known as P-bodies [52-54]. In fact, P-bodies are considered essential for miRNA function, and the current assumption is based on the evidence that P-bodies contain separate compartments for RISC assembly and RISC recruitment of silencing proteins of both the Slicer-dependent silencing path (deadenylation enzymes Ccr4, Not1, Pop2, decapping enzymes, nucleases
Xrn1p, all involved in mRNA degradation) and the Slicerindependent silencing path (p54, FMRP, Gemin5, RAP55, involved in miRNA mediated translational repression and mRNA storage) (Figure 1) [55-58].

\section{MicroRNAs involvement in lung cancer carcinogenesis}

If we consider the numerous activities carried out by miRNAs, their involvement in cell proliferation, apoptosis, gene expression regulation and all the biological processes above mentioned, it is clear that their dysregulation may be involved in various human diseases.

Several studies have shown the involvement of miRNA deregulation and aberrant expression in the carcinogenesis of various organs, including lung cancer [59-60]. Recently, miRNAs have been classified into oncomiRNAs (Table 2) and tumor suppressor miRNAs (Table 3 ) in relation to their function in carcinogenic processes.

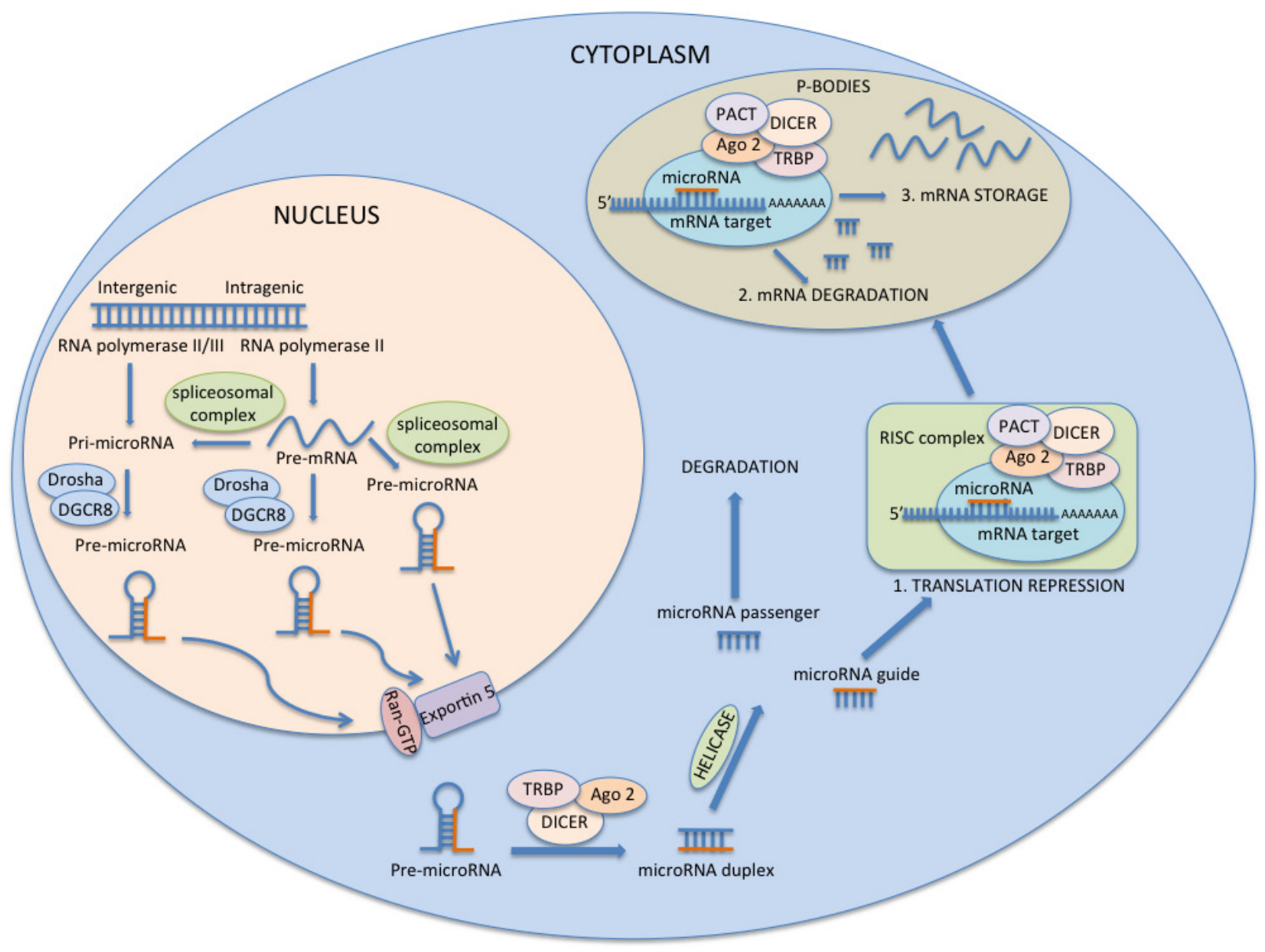

Figure 1: MicroRNAs biogenesis and function: miRNAs are transcribed by RNA polymerase II/III and produce intermediate primary transcripts termed pri-miRNAs, which subsequently undergo a nuclear cleavage by a multiprotein complex (Drosha/ DGCR8) leading to the genesis of pre-miRNAs. Pre-miRNAs are transported to cytoplasm by the RAN GTP-dependent transporter exportin 5 and are further processed by the enzyme Dicer, resulting into a 22 nucleotide long miRNA duplex formed by a passenger strand and a guide strand. Only the guide strand, which results in 18-25 nucleotide long mature miRNA duplex, becomes part of the miRNAinduced silencing complex (miRISC) and mediates gene silencing by interfering with translational process or inducing mRNA degradation and storage into the P-bodies. 
Table 2: Dysregulated oncogenic miRNAs in lung cancer

\begin{tabular}{|l|l|l|l|}
\hline Oncogenic miRNAs & Genomic location & Expression & Target genes \\
\hline miR-21 & $17 \mathrm{q} 23.2$ & Upregulated & $\begin{array}{l}\text { PTEN ,Spry1, Spry2, Btg2, } \\
\text { Pdcd4, Apaf1, FasL, RhoB }\end{array}$ \\
\hline miR-17-92 & $13 \mathrm{q} 31.3$ & Upregulated & $\begin{array}{l}\text { p21, CTGF, Tsp1, PTEN, } \\
\text { Bim, HIF-1 } \alpha\end{array}$ \\
\hline miR-221/222 & Xp11.3 & Upregulated & $\begin{array}{l}\text { Kit, p27 kip1, PTEN/ } \\
\text { TIMP3, PUMA, TRAIL }\end{array}$ \\
\hline miR-155 & $21 \mathrm{q} 21.3$ & Upregulated & $\begin{array}{l}\text { CASP3, TP53BP1, SOCS1, } \\
\text { PTEN, PDC4, SHIP1 }\end{array}$ \\
\hline miR-494 & $14 \mathrm{q} 32.31$ & Upregulated & PTEN, CASP3/7, Bim \\
\hline miR-328 & $16 \mathrm{q} 22.1$ & Upregulated & $\begin{array}{l}\text { PRKCA, VEGF-D, } \\
\text { NOTCH1, IL1- } \alpha, \text { IL1- } \beta,\end{array}$ \\
\hline miR-106 & Xq26.2 $\gamma$ & RB \\
\hline miR-150 & $19 \mathrm{q} 13.33$ & Upregulated & TP53 \\
\hline miR-301 & $17 \mathrm{q} 22$ & Upregulated & SMAD4, PTEN, Bim \\
\hline miR-10b & $2 \mathrm{q} 31.1$ & Upregulated & HOXD10, PTEN \\
\hline miR-93, miR-98, miR-197 & 7q22.1, Xp11.22, 1p13.3 & Upregulated & FUS1 \\
\hline
\end{tabular}

Table 3: Dysregulated tumor suppressive miRNAs in lung cancer

\begin{tabular}{|l|l|l|l|}
\hline Tumor suppressive miRNAs & Genomic location & Expression & Target genes in lung cancer \\
\hline let-7 family & $\begin{array}{l}13 \text { members located on nine } \\
\text { different chromosomes }\end{array}$ & Downregulated & $\begin{array}{l}\text { KRAS, CDC25a, CDK6, } \\
\text { c-MYC, CCND1, BCL-2, } \\
\text { HMG2A }\end{array}$ \\
\hline miR-143 & $5 \mathrm{q} 32$ & Downregulated & $\begin{array}{l}\text { c-MYC, EGFR, NUDT1, } \\
\text { OCT4, ERK5, KRAS, } \\
\text { MMP-13, COX-2, EMT, } \\
\text { CD44v3 }\end{array}$ \\
\hline miR-145 & $5 \mathrm{q} 32$ & Downregulated & $\begin{array}{l}\text { c-MYC, EGFR, NUDT1, } \\
\text { OCT4, CDK4 }\end{array}$ \\
\hline miR-34a, miR-34b, miR-34c & $1 \mathrm{p} 36.22,11 \mathrm{q} 23.1,11 \mathrm{q} 23.1$ & Downregulated & $\begin{array}{l}\text { CDK4, CDK6, c-MYC, } \\
\text { MET, E2F, SIRT, AXL25A, } \\
\text { SNAIL-1, PDGFRa/b }\end{array}$ \\
\hline $\begin{array}{l}\text { miR-449a, miR-449b, miR- } \\
449 \mathrm{c}\end{array}$ & $5 \mathrm{q} 11.2$ & $\begin{array}{l}\text { CDK4, CDK6, c-MYC, } \\
\text { CCND1, CCNE2, CDC25A, } \\
\text { MET, E2F, SIRT, AXL, } \\
\text { SNAIL-1, PDGFRa/b }\end{array}$ \\
\hline miR-15-16 & $13 \mathrm{q} 14$ & $\begin{array}{l}\text { Bcl-2, CDC2, CCND1 } \\
\text { ETS1, JUN, MCL1, } \\
\text { MSH2, PDCD4, PDCD6IP, } \\
\text { RAB9B, WT1, WNT3A }\end{array}$ \\
\hline miR-29a, miR-29b, miR-29c & $7 \mathrm{q} 32.3,7 \mathrm{q} 32.3,1 \mathrm{q} 32.2$ & Downregulated & $\begin{array}{l}\text { DNMT3A, DNMT3B, } \\
\text { MCL-1 }\end{array}$ \\
\hline $\begin{array}{l}\text { miR-200a, miR-200b, miR- } \\
429\end{array}$ & $1 \mathrm{p} 36.33$ & Downregulated & ZEB1, ZEB2, Flt1, GATA3 \\
\hline miR-200c and miR-141 & $12 \mathrm{p} 13.31$ & Downregulated & $\begin{array}{l}\text { Flt1, GATA3, KRAS, } \\
\text { MAPK }\end{array}$ \\
\hline miR-126, miR-128b & $9 \mathrm{q} 34.3,2 \mathrm{q} 21.3$ & Downregulated & $\begin{array}{l}\text { VEGF, CRK, SLC7A5, } \\
\text { EGFR }\end{array}$ \\
\hline $\begin{array}{l}\text { miR-133a-1, miR-133a-2, } \\
\text { miR-133b }\end{array}$ & $18 \mathrm{q} 11.2,20 \mathrm{q} 13.33,6 \mathrm{p} 12.2$ & Downregulated & ARPC5, GSTP1, Sp1 \\
\hline miR-206 & $6 \mathrm{p} 12.2$ & Downregulated & CCND1, GSTP1 \\
\hline
\end{tabular}


Actually, different miRNAs are not yet well defined, showing both oncogenic and suppressive activities. Among them miR-7, miR-31, miR-125 and miR-183 family members were found disrupted in lung cancer [60].

\section{Oncogenic miRNAs in lung cancer}

\section{miR-21}

Located at chromosome 17, miR-21 is one of the most studied miRNA and is the first one termed "oncomir." It was found upregulated in different forms of solid tumors, including lung cancer [61]. MiR-21 is an anti-apoptotic miRNA and is regulated by the EGFR pathway, correlating with EGFR phosphorylated levels [62]. It has been proven that miR-21 stimulates cell growth and the invasion of NSCLC cells by targeting PTEN (Phosphatase and tensin homolog), enhancing the RAS/ MEK/ERK pathway through their negative regulators repression (Spry1, Spry2, Btg2, Pdcd4) and repressing the expression of several pro-apoptotic proteins such as Apaf1, FasL, RhoB, Pdcd4 [62-65]. MiR-21 has also been found to be upregulated by KRAS in NSCLC, both in vitro and in vivo through MAPK/AP-1 activation [63-65].

\section{miR-17-92 cluster}

This miRNA cluster includes different members (miR-17, miR-18a, miR-19a, miR-20a, miR-19b-1, miR92a-1), all encoded by a gene located on chromosome $13 \mathrm{q} 31$, and involved in several oncogenic processes like cellular proliferation, angiogenesis and apoptosis. In 2005, the Takahashi group provided evidence of their involvement in lung cancer discovering that the miRNA 17-92 cluster was strongly overexpressed in a panel of 19 lung cancer cell lines [66].

Furthermore, malignancies harboring c-MYC upregulation, such as small cell lung cancer and various B cell lymphomas, exhibit high miRNAs 17-92 levels, proving that miRNAs $17-92$ cluster is under c-MYC control. In particular, miR-17-92 functions are achieved by repressing different targets involved in proliferation inhibition (p21), angiogenesis (CTGF, Tsp1) and by repressing pro-apoptotic agents (PTEN, Bim) [67]. HIF$1 \alpha$ is another direct target of miR-17-92, and recent evidence suggests that the induction of miR-17-92 may play a role in c-MYC mediated repression of HIF-1 $\alpha$ [68]. However, these authors also observed that miR1792 repressed HIF-1 $\alpha$ only under a normoxic condition, whereas HIF-1 $\alpha$ was markedly induced under hypoxia, regardless of miR-17-92 levels [68]. Even though HIF-1 $\alpha$ has been found upregulated in several cancers, probably because of the intratumoral hypoxia, its involvement in cancer initiation and progression is not clear. In fact, the ability of HIF-1 $\alpha$ to induce cell cycle arrest by activating p21 or p27, and induce apoptosis by stabilization of p53 and transactivation of BNIP3, has been well defined [69-
70]. Similarly, HIF-1 $\alpha$ represses c-MYC transcriptional activity and function, suggesting another role in cell cycle negative control [71]. The transcription factor E2F1 is an additional target of c-MYC that promotes cell cycle progression. O'Donnell et al. demonstrated that expression of E2F1 is negatively regulated by two miRNAs of this family, miR-17-5p and miR-20 [72]. Later, in 2007, Woods and his group proposed a model in which miR-17-92 promoted cellular proliferation through the enhancement of a proliferative E2F3 transcriptional network rather than the pro-apoptotic E2F1 activity [73]. In conclusion, two main mechanisms, which lead to an overexpression of the miR-17-92 cluster, can be observed in lung cancers: amplification of the miRNA cluster and increased expression of the c-MYC gene [66].

\section{miR-221/222}

MiR-221 and miR-222 are two highly homologous miRNAs encoded in tandem on the $\mathrm{X}$ chromosome, and involved in the development and progression of different types of epithelial cancers [77]. A growing body of evidence suggests that miR-221/222 are involved in the resistance of NSCLC cells to TRAIL (Apo2L/ TNF $\alpha$-related apoptosis-inducing ligand) [74], and this hypothesis are further corroborated by the observation that NSCLC cells transfection with anti-miR-221/222 results in TRAIL sensitivity in NSCLC [74]. Moreover, Kit and p27 kip1 have been identified as the main targets of this miRNA cluster in NSCLC, and the decreased levels of p27 kip1 seem to account for the reduced sensitivity to TRAILinduced apoptosis [74]. However, additional targets of miRNAs 221-222, such as PTEN/TIMP3 [75] and PUMA (also known as Bcl-2 binding component 3) [76], seem to mediate TRAIL resistance, migration and invasiveness, thus correlating with the frequent overexpression of these miRNAs in epithelial cancers, including lung cancers [78]. Not only, but the MET oncogene is involved in miR-221/222 activation, through the JNK, AP-1 and in particular c-Jun transcription factor [75].

Additionally, miRNAs 221-222 upregulation in NSCLC is involved in tumorigenesis and aggressive biological behavior through the activation of PI3K/ Akt pathway and metallopeptidases [75].

\section{miR-155}

Although most proof of miR-155 oncogenic roles derives from studies on lymphatic system malignancies, its involvement in cancer pathogenesis has also been confirmed in breast, liver and especially lung cancer [79].

MiR-155 oncogenetic properties depend on its antiapoptotic function, due to the blockage of caspase 3 activity and suppression of pro-apopotic genes such as TP53BP1 [80-81].

MiR-155 also promotes cell proliferation through the repression of SOCS1 [82] and by downregulating several tumor suppressors such as PTEN, PDC4 and SHIP1, leading to the activation of the Akt pathway [83]. 
MiR-155 is also regulated by the transforming growth factor-beta/Smad 4 pathway and plays a role in cell invasion by targeting RhoA [84].

\section{miR-494, miR-27a, miR-328}

miR-494 acts as an oncomir by repressing apoptosis processes targeting PTEN and caspases $3 / 7$, whose levels are all decreased in human bronchial epithelial cells (transformed by chemical carcinogen anti-Benzo-APyrene-Diol-Epoxide) harboring miR-494 upregulation [85]. Furthermore, miR-494, once activated by the ERK $1 / 2$ pathway in NSCLC, targets BIM 3' UTR, inducing the downregulation of BIM and consequently inhibiting apoptosis [86].

MiR-27a overexpression promotes cell growth by the suppression of the target gene FBXW7 which is involved in the malignant transformation of the human bronchial epithelial cells [87].

MiRNA 328 upregulation has recently been associated with cell migration and NSCLC brain metastases by controlling the VEGF/IL1 signaling pathway. Many of the miR-328 targets control this signaling pathway leading to loss of cell adhesion and increased migration. These target genes included PRKCA, VEGF-D, NOTCH1, IL1-alpha, IL1-beta and PLC-gamma [88].

\section{miR-106, miR-150, miR-131, miR-10b}

miR-106 and miR-150 were identified as oncomirs in lung cancer because of their activities in regulating growth and apoptosis. MiR-106 targets RB while miR150 targets TP53 [89]. MiR-301 is another oncomir upregulated in several types of cancer, including NSCLC, and involved in smad4 repression through the direct binding to 3' UTR [90-91]. Recently, also miR-10b has been reported to be overexpressed in NSCLC, playing a role in the invasion and metastasis development by HOXD10 inhibition and RhoC upregulation [92].

\section{miR-93, miR-98, miR-197}

These miRNAs promote lung cancer growth by repressing FUS1, a supposed tumor suppressor gene which is often downregulated in lung cancers. FUS1 works as a pro-apoptotic agent through the activation of the intrinsic mitochondrial pathway and the blockage of tyrosine kinases function, such as EGFR, PDGFR, AKT, c-Abl, c-Kit. [93-95].

\section{Tumor suppressive miRNAs in lung cancer}

\section{let-7 family}

let-7 was the first miRNA identified as dysregulated in human lung cancer [96]. The let-7 miRNA family are important regulators in controlling lung cancer oncogenes expression by binding to the 3' untranslated regions of their target mRNAs and lower levels have been found in NSCLC [97-98]. let-7 directly regulates many key cell cycle proto-oncogenes, such as KRAS, CDC25a, CDK6, c-MYC, cyclin D, BCL-2 and in this way controls cell proliferation by negatively regulating the pathways promoting the G1 to $\mathrm{S}$ transition [99]. One of the most interesting aspects of the let-7 family is that the 3' UTR of KRAS (as well as HRAS, NRAS and various members of RAS GTPase family) contains multiple let-7 binding sites and that the expression of let-7 in lung cancer is inversely correlated to KRAS expression [98-100]. Moreover, Chin et al. described a novel SNP (Single Nucleotide Polymorphism) in the 3' UTR of the KRAS gene that influences the let-7 binding to its target site. This variant, the let-7 complementary site (LCS6) in the KRAS 3' UTR, is associated with KRAS gene upregulation and let-7 lower levels [101]; although this polymorphism correlates with a modest increase in lung cancer risk [101], other studies did not find an association between the LCS6 polymorphism and lung cancer survival, limiting its clinical usefulness in predicting an increased risk for NSCLC [102]. Another target of let-7 is HMG2A, a transcription factor involved in the activation of several genes that influence the cell growth, differentiation and proliferation. HMG2A is highly expressed in lung cancer and let-7 regulates its levels by destabilizing its mRNA through the 3' UTR binding [103-105].

Lastly, a recent study identified HOXA1 as a new target of the let-7 family. In this study Min Zhan et al. demonstrated that let-7c represses NSCLC cell proliferation and tumorigenesis by directly targeting the 3' UTR of HOXA1 mRNA, which subsequently reduced the expression of CCND1, CDC25A and CDK2 [106].

\section{miR-143, miR-145}

miR-143 and miR-145 are co-transcribed from a bicistronic gene cluster on chromosome 5 , and have been identified as tumor suppressors in different types of cancer such as bladder, gastric, cervical, breast, prostate, leukemia and lung in which furthermore they are strongly downregulated [107-114]. Both miR-143 and miR-145 are able to inhibit cell growth, proliferation and migration of lung cancer cells through the repression of c-MYC, EGFR, NUDT1 and OCT4 [115-117]. In addition, miR145 also induces cell cycle arrest in G1 by targeting CDK4 [116]. Many other relevant targets of miRNA 143 have recently been identified: ERK5, KRAS, MMP-13, COX-2 and EMT [118]. Moreover, miR-43 inhibits the migration and invasion of NSCLC by targeting CD44v3, a transmembrane glycoprotein involved in many cellular processes like the regulation of cell division, survival, migration and adhesion [118-119].

\section{miR 34-449 family}

The miR-34 family consists of tumor-suppressive miRNAs (miR-34a, miR-34b, miR-34c) reported to be under $\mathrm{p} 53$ regulation and involved in controlling apoptosis and G1 cell cycle arrest. MiR-34 reduced expression 
has been found in various cancers, including NSCLC [120-121]. The miR-449 cluster (miR-449a, miR-449b, miR-449c) belongs to the same family as miR-34 (p53responsive microRNAs) [122]. Specifically, both miRNA 34 and 449 lead to cell cycle arrest, targeting CDK4, CDK6, c-MYC, CCND1, CCNE2, CDC25A, MET and $\mathrm{E} 2 \mathrm{~F}$ transcription factors family, induce apoptosis targeting $\mathrm{Bcl}-2$, n-MYC, HDAC1 and upregulate p53 through the repression of deacetylase gene SIRT1 [122124]. miR-34 and miR-449 are also involved in the inhibition of NSCLC cell migration and invasion by suppression of AXL and SNAIL-1, respectively a tyrosinekinase receptor and a zinc-finger protein involved in cellular migration, proliferation and cancer cell epithelialmesenchymal transition [123-124]. Other targets identified in NCSLC are HMGA2, SERPINE1 (both implicated in cell migration and cancer invasiveness) and PDGFRa/b, whose downregulation inhibits proliferation, cell growth, and enhances TRAIL-induced apoptosis [125-126].

\section{miR-15-16}

miR-15 and miR-16 are important negative regulators of cell cycle progression in NSCLC and in many other solid tumors, as well as in hematologic malignancies such as chronic lymphatic leukemia [127128]. Located at chromosome 13q14, these miRNAs are implicated in cell cycle control and apoptosis by targeting different molecules involved in these processes (Bcl-2, CDC2, CCND1, ETS1, JUN, MCL1, MSH2, PDCD4, PDCD6IP, RAB9B, WT1, WNT3A) [128]. Furthermore, a recent study has shown that miR-15a, miR-16-1 cluster and related miR-15b, miR-16-2 cluster are direct transcriptional targets of E2F1 and control E2F-dependent cell proliferation by cyclin $\mathrm{E}$ gene repression, thus inhibiting the G1/S transition [129]. Another interesting observation is that in NSCLC the miR-15/16 cluster directly regulates cyclin D1, D2, E1, CDK4/6 and that cyclin D1 and miR-15/16 expression levels are inversely correlated. Moreover it has been demonstrated that, when combined, miR-34a and miR-15a/16 induce a deeper and longer lasting G1 cell cycle arrest than the repression due to only the additive effect of two miRNAs separately, suggesting a strong cooperation between them [130].

\section{miR-29 family}

The tumor suppressor miR-29 family includes miR29a, miR-29b, miR-29c, and several studies have reported its downregulation in NSCLC [61, 131]. MiRNA 29 has been found to regulate DNMT3A and 3B, two DNA methyltransferases repeatedly found to be overexpressed in different kind of malignacies, including lung cancer. By targeting DNMT3A and 3B, the miRNA 29 family controls tumorigenicity both in vivo and in vitro through a demethylation process, thus leading to the re-expression of silenced tumor suppressor genes such as FHIT and WWOX [132]. Furthermore, miRNA 29 suppresses tristetraprolin (TTP) and MCL-1, respectively a protein involved in epithelial cells polarity and metastasis, and an antiapoptotic member of the Bcl-2 family [133-134].

\section{miR-200 family/miR-205}

The miR-200 family includes five members: miR200a, miR-200b, miR-429, miR-200c and miR-141; in humans miR-200a, miR-200b and miR-429 co-localize at chromosome 1, while miR-200c and miR-141 at chromosome 12 [135].

Along with miR-205, this family inhibits epithelial mesenchymal transition by targeting ZEB1 and ZEB2; in lung cancer miR-200c overexpression causes a reduced expression of ZEB1 and derepression of E-cadherin, the trascriptional target of ZEB1 [136].

The Kurie group validated Flt1 as one of miR-200s targets [137]; they subsequently discovered that GATA3, which is a component of the Notch signaling pathway, was downregulated by miR-200s [138]. On the other side, Korpal et al. demonstrated that metastatic colonization to the lung was promoted by miR-200s by targeting Sec23a [139].

In addition, also KRAS was recognized as a target of miR-200c and its upregulation plays a role in overcoming chemotherapeutic treatment [140]. Furthermore, miR-200c strongly interacts with the MAPK and ERBB signaling pathway by controlling a multitude of target genes, such as the adaptor proteins Shc and Sos, but also kinases like MEKK1 and PKC or transcription factors, mainly SRF and JUN. This evidence suggests that miR-200c is a potent inhibitor of tumor progression and therapy resistance [140].

\section{miR-126/126*, miR-128b}

MiR-126 (or miR-126-3p) and its complement miR-126* (miR-126-5p or miR-123) are encoded by the inton 7 of Growth factor-like domain 7 (EGFL7) gene [141]. They are considered as tumor suppressor miRNAs because of their activity in decreasing lung cancer cell growth and inducing cell cycle arrest at G1 phase by targeting VEGF [141]. In NSCLC, miR-126/126* also play a role in inhibiting cell migration, adhesion invasion by targeting CRK [142], and several studies have reported their downregulation in NSCLC [143-145].

Moreover, it was demonstrated that miR-26 family is under-expressed in the majority of SCLC tumors, wheras its upregulation solws down the cellular proliferation by delaying the cells in the G1 phase and by targeting SLC7A5 [146].

MiR-128b is mapped on chromosome 3, within the 18th intron of ARPP21 gene [147] and a frequent loss of heterozygosity (LOH) [148] in NSCLC was discovered; EGFR is a direct target of miR-128b, so its reduced expression promotes carcinogenesis by the derepression of this oncogene [148].

Donzelli et al. demonstrated that in NSCLC, mutant $\mathrm{p} 53 \mathrm{R} 175 \mathrm{H}$ induces the expression of miR-128 through the transactivation of its host gene ARPP21, resulting in the 
increased chemoresistance of cancer cells. Indeed, miR128 expression causes p21Wafl upregulation through the inhibition of the transcriptional repressor E2F5 and its accumulation in the cytoplasm, a feature associated with the anti-apoptotic effect of p21waf1 [147].

\section{miR-133, miR-206}

MiR-133 and miR-206 have been termed "muscle specific" miRNAs since they are highly expressed in cardiac and smooth muscle tissues [149-150]. Recently, miRNAs expression signatures analysis revealed that miR-133 expression levels are significantly reduced in squamous cell carcinomas (SqCC), and it was demonstrated that its restoration causes the inhibition of cancer cell proliferation [151].

Multiple targets of miR-133 were identified, and two of them were confirmed in lung cancer cells, ARPC5 and GSTP1 [151].

In lung tumors, miR-206 expression levels were markedly lower in highly metastatic forms than in low metastatic tumors and normal lung tissues, and its upregulation causes the induction of apoptosis, the inhibition of lung cancer cell proliferation, migration and invasion [149].

\section{MicroRNAs in lung cancer diagnosis}

Despite the progress of the diagnostic procedures, to date a population-based screening does not exist, and around the $40 \%$ of the patients with NSCLC are diagnosed in an already locally advanced or metastatic stages (IIIA/B, IV), therefore with an unresectable disease [152]. Aberle et al. have shown a $20 \%$ reduction in lung cancer mortality rates with low-dose spiral CT compared to chest radiography, in a selected older, high-risk population. Nevertheless, this study also demonstrated an elevated number of false positive results, probably due to the presence of non-pathological intraparenchimal lymph nodes or non-calcified granulomas [153]. It is therefore of primary importance to develop non-invasive confirmation tests to overcome the problem of over-diagnosis and over-treatment due to the false positive CT. Moreover, the development of minimally invasive and sensitive biomarkers could be useful also for screening and early diagnosis of lung cancers.

MiRNAs represent a class of molecules that meets these criteria. Their expression patterns in human cancers appear to be tissue-specific, and they are stable in paraffinembedded tissues as well as in body fluids, even in plasma and serum, as opposed to mRNAs which are easily degraded by ribonucleases. These features make them potential biomarkers for cancer detection [154-156].

Yanaihara et al. in 2006 discriminated lung cancer tissues from adjacent noncancerous lung tissue using miRNA microarray analysis, and found a unique miRNA profile in lung cancer tissue, specifically a high expression of let-7a-2 and low expression of miR-155 [131]. Later, Shen et al. studied 12 miRNAs as potential plasma biomarkers. Among them, miR21, miR-126, miR-210, and miR-486-5p showed a significant concordance between the expression levels in plasma and the corresponding tumor tissues $(P<0.05)$ yielding $86.22 \%$ sensitivity and $96.55 \%$ specificity in discriminating NSCLC patients from the healthy control group. Moreover, these four miRNAs also showed a higher sensitivity in diagnosis of lung adenocarcinomas compared with squamous cell carcinomas $(91.67 \%$ vs. $82.35 \%, \mathrm{P}<0.05)$ [157]. Similary, Zheng et al. found that the levels of miR-155, miR-197, and miR-182 in the plasma of lung cancer patients were significantly $(\mathrm{P}<$ 0.001 ) elevated compared with control groups, and further that the simultaneous combination of these 3 miRNAs yielded $81.33 \%$ sensitivity and $86.76 \%$ specificity in distinguishing lung cancer patients from control groups [158].

Additionally, miR-30a, miR-140-3p, miR-182, miR-210, and miR-486-5p were identified to discriminate squamous cell carcinoma from non-cancerous lung tissue with an accuracy of $94.1 \%$ in a training cohort (34 patients) and $96.2 \%$ in a test cohort (26 patients) [159]. Not only, miR-1254 and miR-574-5p increased serum levels were able to discriminate early-stage NSCLC samples from controls with over $70 \%$ sensitivity and specificity, in two separate cohorts [211]. Bianchi et al. developed a miRNA signature, based on the detection of 34 microRNAs from serum, which made it possible to identify patients with early stage NSCLCs in a population of asymptomatic high-risk individuals with $80 \%$ accuracy, and also to differentiate between the malignant and the benign lesions detected by low-dose TC. [212]. In accordance with Bianchi F., Boeri et al. validated a 13 miRNAs diagnostic signature of NSCLC that can differentiate aggressive from indolent tumors detected by low-dose TC with almost $80 \%$ accuracy. Interestingly, they showed that this signature appears months before NSCLC can be diagnosed by low-dose TC, especially in patients whose tumors had aggressive features and behavior [160]. Moreover, Barshac et. al identified different miRNA expression profiles between primary lung tumors and metastases, in particular miRNA-182 and miRNA-126 overexpression was found respectively in primary lung cancers and in metastatic tumors [161].

Since it is the most easily accessible biological fluid, different studies evaluated the possibility of miRNAs detection in sputum. Ying Xie et al. examined miRNA 21 and miRNA155 expression by real-time reverse transcription polymerase chain reaction (RT-PCR) in sputum of 23 patients with NSCLC and 17 cancer-free subjects. MiR-21 expression in the sputum specimens was significantly higher in patients with NSCLC than cancerfree control group $(p<0.0001)$ [162]. Yu et al. found that the combined overexpression of miR-21, miR-200b, miR- 
375 , and miR-486 in surgical tissues and sputum were biomarkers for lung adenocarcinoma diagnosis, with $80.6 \%$ sensitivity and $91.7 \%$ specificity [163]. Similarly, Xing L. et al. developed a sputum-based biomarker panel based on three miRNAs (miR-205, miR-210 and miR-708) for the diagnosis of squamous cell lung cancer, yielding a sensitivity of $73 \%$ and a specificity of $96 \%$ [164]. Finally, Roa WH. et al. optimized a five miRNAs panel (miR-21, miR-143, miR-155, miR-210, miR-372) for early NSCLC detection, with a $83.3 \%$ sensitivity and $100 \%$ specificity [165].

An ulterior feature of the use of microRNAs for diagnostic purposes, is the ability to discriminate between different histological types. Lebanony $\mathrm{D}$ et al. validated a microRNA-based qRT-PCR assay that measures the expression levels of miR-205, reaching a sensitivity of $96 \%$ and specificity of $90 \%$ in the identification of squamous cell lung carcinomas [166]. Similar results were found by Boeri et al., confirming the role of miR205 and miR-21 expressions in discriminating between adenocarcinoma and squamous cell carcinoma [160]. Additionally, Bishop et al. showed a 100\% concordance between the diagnoses established by conventional (histologic features and immunohistochemical profiles) and miRNA-based methods (quantitative reverse transcription-PCR diagnostic assay), using miRNA 205 overexpression as a positive biomarker for squamous cell carcinoma [167]. Landi et al. identified a five-miRNA signature (miR-25, miR-34c-5p, miR-191, let- 7e, miR34a) that strongly differentiated squamous cell carcinoma from adenocarcinoma (global $\mathrm{P}<0.0001$ ), and reported that the lower expression level of this signature correlated with the poor overall survival rates of squamous cell carcinoma patients [168].

In summary, all of this evidence shows that miRNAs are useful biomarkers to differentiate lung cancer tissue from healthy tissue, and specifically how they can discriminate between the different histological types of lung cancer, or between lung primary tumors and metastases. Moreover, as mentioned above, the possibility of their detection in sputum specimens could be particularly helpful in early lung cancer diagnosis.

\section{Prognostic role of miRNAs in lung cancer}

In 2004, Takamizawa et al. reported that reduced let7 expression was significantly associated with shortened postoperative survival in patients affected by NSCLC, suggesting the potential value of miRNAs in defining lung cancer prognosis for the first time [96]. Similar results were obtained by Yanaihara et al., who showed that overexpression of the precursor of miR-155 and the downregulation of let-7a-2 correlated with poor survival in NSCLC patients [131]. Yu et al. validated a further miRNA signature based on five miRNAs, including let-7 (let-7a, miR-137, miR-182, miR-221, miR-372).
They found that patients with high-risk scores in their microRNA signatures had poor overall and disease-free survivals compared to the low-risk score patients [169]. In this respect, Heegaard et al. studied paired serum and plasma samples from 220 patients with early stage NSCLC and 220 controls, using qRT-PCR to measure 30 different circulating miRNAs. The expression of miR146b, miR-221, let-7a, miR-155, miR-17-5p, miR-27a and miR-106a was significantly reduced in the serum of patients with NSCLC and miR-29c was significantly increased, while low levels of plasma-miRNA let-7b were statistically significantly associated with poor survival [170]. Xiaogang Tan et al. developed a further 5 five miRNAs signature that could distinguish SCC from normal lung tissues, and demonstrated that high expression of miRNA-31 was associated with poor survival in stage I-III squamous cell lung carcinoma [159]. MiR-31 was also validated as a marker for lymph node metastasis as well as a predictor for survival outcomes in patients with lung adenocarcinoma [171].

Lately, many other miRNAs have been studied as possible prognostic factors, in particular Raponi et al. reported that high expression of miR-146b correlated with a poor overall survival in patients undergoing radical surgery for squamous cell carcinoma, also experiencing the same trend in the expression level of miR-155 in the same group of patients [172]. Nevertheless, Wu et al. showed that high miR-19b and low miR-146a expression in NSCLC tissues were associated with higher TNM stage, lymph node metastasis and poorer survival $(\mathrm{P}<0.05)$ [173].

Furthermore, $\mathrm{Li}$ et al. detected the expression of miR-146 in NSCLC tissues and normal tissues by MISH (miRNA in situ hybridization), concluding that high expression level of this miRNA can predict NSCLC prognosis [174].

Recently, the possible prognostic role of miR155 has been also explored, and several studies confirm its value in lung cancer diagnosis, prognosis and therapy [79]. In this regard, Donnem et al. evaluated the prognostic impact of miR-155 overexpression in 91 squamous cell carcinomas, 95 adenocarcinomas, 31 large cell carcinomas and 18 bronchioalveolar carcinomas by in situ hybridization. They found that in patients affected by adenocarcinoma, high miR-155 expression levels tended to assume a negative prognostic significance on survival in univariate analysis $(\mathrm{P}=0.086)$, and were also an independent prognostic factor in multivariate analysis (HR 1.87, CI 95\% $1.01-3.48, \mathrm{P}=0.047$ ). In the group of squamous cell carcinomas with lymph node metastasis, miR-155 had a positive prognostic impact on survival in both univariate $(\mathrm{P}=0.034)$ and multivariate analysis (HR 0.45, CI 95\% 0.21-0.96, $\mathrm{P}=0.039$ ). These data suggest that the prognostic role of miRNA 155 could be different according to the histological subtype and nodal status [175]. Despite this, high miR-155 expression levels 
were found to be associated with poor outcome in lung squamous cell carcinoma [172]. Nonetheless, Tong-Peng $\mathrm{Xu}$ et al. conducted a meta-analysis of 15 published articles including 2,463 subjects. They demonstrated that patients with high miR-155 expression generally had a poor outcome, while stratified analysis showed that miR-155 overexpression was not statistically correlated to overall survival in lung cancer; on the other hand, when the hazard ratio for recurrence free survival (RFS) and cancer specific survival (CSS) was combined, the increased expression of miR-155 was significantly associated with RFS as well as CSS [176]. Therefore, the role of miR-155 in lung cancer prognosis requires further investigation.

Also, miR-126 family received particular attention for its role in lung cancer pathogenesis, especially for the ability to regulate angiogenesis through VEGF-A release from the tumor cells. Donnem T. et al. showed that miR126 overexpression was a significant negative prognostic marker in SCCs $(\mathrm{P}<001)$ and in lymph node positive patients [177].

Various studies evaluated also the prognostic role of high miR-21 levels. Markou A. et al. demonstrated for the first time that mature miR-21 overexpression, achieved using qRT-PCR, correlated with poor overall survival (OS) $(\mathrm{P}=0.027)$ [178]. Gao W. et al. found that high miRNA-21 and low 181 miRNA levels were associated with poor survival, independent of clinical covariates, including TNM staging and lymph node status [179]. In a further study, the same investigators showed that the high-level expression of miR-21 in human primary squamous cell lung carcinoma was significantly correlated to shortened survival time [143]. Liu XG et al. confirmed that high expression of serum miR-21 and tumor miR-200c are associated with poor prognosis in lung cancer patients [180]. These findings were confirmed and expanded upon by many other studies [181-183], in particular Voortman et al., who determined the expression of miR-21, miR$29 \mathrm{~b}, \mathrm{miR}-34 \mathrm{a} / \mathrm{b} / \mathrm{c}, \mathrm{miR}-155$ and let-7a, by quantitative real-time PCR in paraffin embedded formalin fixed tumor specimens from 639 patients enrolled in the International Adjuvant Lung Cancer Trial. Surprisingly, only the low expression of miR-21 was associated with shorter survival time [182].

Several other miRNAs have been investigated individually because of their potential role in the prediction of the lung cancer prognosis, in particular low expression levels of miR-34a, miR-374a, miR-181a, miR221, miR-200c and miR-218 were reported to associate with a poor survival or high risk recurrence in lung cancers [60].

Arora et al. found miR-328 to be a marker for patients with higher risk for brain metastases. In this study, both PRKCA and IL1-beta were identified as targets of miR-328, supporting evidence that miR-328 leads to increased migration of NSCLC cells, through this pathway as well [89]. Similarly, miRNA-145 downregulation was found to play various important roles in the development of brain metastases from lung adenocarcinoma [184]. Finally, the latest evidence indicates that epigenetic changes in miRNA expression may contribute to defining the prognosis of patients with NSCLC. Specifically, Wang Z. et al. demonstrated that patients affected by NSCLC and underwent curative surgery (without receiving any subsequent adjuvant therapy) with aberrant DNA methylation of miR-34b/c (but not 34a), had a high probability of recurrence, poor overall survival and poor disease-free survival [185]. Again, Gallardo et al. found a correlation between MIRN34A gene promoter region methylation and miR-34a expression $(\mathrm{P}=0.008)$ [186]. They also found that the frequency of p53 mutations was significantly higher in patients with low miR-34a expression, and the group of patients harboring both p53 mutations and low miR-34a expression had a poor prognosis [186]. The same role of $\mathrm{miR}-34 \mathrm{~b} / \mathrm{c}$ aberrant methylation was reported even in SCLC [187]. Kitano et al. analyzed the methylation status of miR-152, miR-93, miR-124-1, miR-124-2, and miR-124-3 in 96 NSCLC specimens, discovering that methylation of miR-9-3, miR-124-2, and miR-124-3 were individually associated with an advanced T-factor independent of other clinical covariates, such as age, sex, and smoking habit. They also found that methylation of multiple microRNA loci was associated with a poorer progression-free survival rate in univariate analysis [188]. Not only, but the let-7 miRNA gene family and was found to be hypomethylated in lung adenocarcinomas, while normally methylated in normal human tissues by DNA methyltransferases DNMT1 and DNMT3B [189]. Further studies have also confirmed that miR-1 and miR-29 family are subject to epigenetic regulation, prospecting a possible pathogenetic as well as prognostic and therapeutic role [190-191].

Just like epigenetic changes, single-nucleotide polymorphisms (SNP) in miRNAs genes are also involved in lung cancer susceptibility and prognosis [192-193]. Tian Tian et al. showed that the SNP rs11614913 T>C in the pre-miRNA region of miR-196a2 was related with significantly increased risk and poor survival among Chinese patients affected by NSCLC [194]. It should be noted that when the role of miR 196a in the pathogenesis and prediction of patients with NSCLC outcome was recently confirmed, it was found that miR196a is significantly upregulated in NSCLC tissues, and that it is involved in NSCLC cell proliferation, migration and invasion, mainly via the downregulation of HOXA5. Higher expression of miR-196a in NSCLC tissues was also associated with higher clinical stages and lymph-node metastases [195].

Naturally, SNPs also occur in miRNA target genes and miRNA processing machinery genes. In particular, a SNP in the let-7 binding site at KRAS 3' UTR (LSC6) enhances KRAS expression levels, resulting in increased 
risk of NSCLC in patients who are moderate smokers [101]. Similarly, Xiong F. et al. identified a SNP in the 3'UTR of the L-MYC gene MYCL1 that results in increased susceptibility to SCLC, probably due to a defective interaction between miR-1827 and its complementary MYCL1 3'-UTR binding site [196]. Finally, also SNPs in miRNA processing machinery genes such as Drosha, AGO1, XPO5 were reported associated with lung cancer prognosis, and in the near future may contribute to a further stratification of these patients [197-200].

\section{Predictive role of miRNAs in lung cancer}

Lung cancer therapy has changed enormously over the last years thanks to the discovery of specific mutations (EGFR, KRAS, ALK, ROS1), and thus the introduction of targeted therapies. Certainly, the understanding of the mechanisms of resistance that often affect the outcome of these patients is equally important. The study of the predictive role of miRNAs is still a relatively unexplored frontier that is already of great importance.

Weiss et al. demonstrated that miR-128b directly regulates EGFR and that a loss of heterozygosity in miR$128 \mathrm{~b}$ was significantly associated with survival benefit in patients treated with gefitinib [148]. Similarly Zhong et al. showed that miR-126 restoration enhances gefitinibinduced cytotoxicity in lung cancer cells [201], while Cho et al. found that the restoration of miR-145 inhibits cancer cell growth in lung adenocarcinoma patients with EGFR-activating mutations [202]. Moreover, miR21 is positively regulated by EGFR signaling in cancer cells harboring activating EGFR mutations, and EGFRTKIs can repress the aberrantly increased miR-21 levels, while miR-21 suppression could enhance EGFR TKIs therapeutic effects [203]. In addition, miR-21 was found to be involved in the acquired resistance of EGFR-TKI in NSCLC (in vivo and in vitro), through the downregulation of PTEN, PDCD4 and by the activation PI3K/Akt pathway [204]. Another study showed that miR-7 downregulates EGFR mRNA in different cancer cell lines, including lung cancer. This study confirmed that miR-7 negatively regulates also AKT, and ERK 1/2 [205], whereas Rai et al. also confirmed these results finding that miR-7 ectopic expression allowed EGFR TKIs to overcome resistance in lung cancer cell lines [206].

Noteworthy is the finding that some miRNAs are able to inhibit TRAIL-induced apoptosis in lung cancer cells. TRAIL (TNF-related apoptosis inducing Ligand) is a member of the TNF family involved in programmed cell death in cancer cells [207], and miR-221, miR-222 were found to guide lung cancer resistance to TRAIL therapy by downregulating PTEN and TIMP3, which are both tumor suppressors [75].

The evidence that miR-628 overexpression is associated with resistance to crizotinib treatment, since crizotinib-induced cell death occurs through activation of the caspase- 3 , which is a miR-628 target, is also noteworthy [208-209].

In the case of traditional chemotherapy, mir-181a sensitized A549 cells to the lethal action of cisplatin by stimulating Bax oligomerization as well as through the activation of proapoptotic caspases 9 and 3 [210]. MiR630 , on the other hand, arrests the main manifestations of the DNA damage response to cisplatin such as ATM, p53 and histone H2AX phosphorylation, leading to G0G1 phase cell cycle arrest and a diminished sensitivity of A549 cells to S-G2-M cell cycle arrest [210]. Additionally, miR-17-92 cluster and miR-221/222 were found to enhance lung cancer cell sensitivity to cytotoxic drugs $[66,59,75]$. Furthermore, Gao et al. investigated the role of miR-21 in predicting adjuvant platinumbased chemotherapy response and disease free survival in patients with NSCLC. They found that high levels of miR-21 increased A549 cells resistance to platinum, while reduced miR-21 decreased the resistance of A549 cells to platinum. This data was confirmed in the tissue samples of 58 patients, in which miR-21 expression was significantly increased in platinum-based chemotherapy resistant patients $(\mathrm{n}=58, \mathrm{P}=0.000)$ and also associated to a shorter disease free survival $(P=0.008)$ [213]. Similar findings about miR-503were reported by Qui T. et al., indeed they showed that the expression of miR-503 was decreased in cisplatin-resistant NSCLC cells (A549/ CDDP), compared with the parental A549 cells, and that the overexpression of miR-503 could sensitize the A549/CDDP cells to cisplatin targeting the anti-apoptotic protein $\mathrm{Bcl}-2$, whereas the inhibition of miR-503 was able to increase A549 cell resistance to cisplatin [214]. MiR-135a/b overexpression was found to reduce MCL1 protein levels and sensitize A549 cells to cispatin-induced apoptosis, suggesting a potential role of miR-135a/b loss of function in the development of cisplatin resistance in lung cancer [215].

Finally, miR-101 was discovered to enhance paclitaxel-induced apoptosis in NSCLC cells by the repression of EZH2 [216] and sensitize the A549 NSCLC cell line to cisplatin-induced apoptosis through the caspase 3 pathway [217].

MiRNAs have also been examined for their role in predicting the response of radiation therapy. In particular, let-7b downregulation lead to an important protection from radiation, conversely let- $7 \mathrm{~g}$ downregulation increased radiosensitization in lung cancer cells (A549) while its overexpression can act as protection against radiation damage [218]. As previously reported, miR-21 is often overexpressed in NSCLC, also associated with lymph node metastasis and poor prognosis. Recent data suggests its involvement in the radio-resistance of lung cancer cells by silencing the expression of crucial genes implicated in apoptosis through caspase activation [219].

In conclusion, there is a body of evidence to support the idea that miRNAs may have a predictive role 
in defining response to both biological treatments and traditional chemotherapy. Further studies are required to confirm and extend this data in order to contribute to a better stratification of patients and thus develop personalized therapeutic strategies.

\section{MiRNAs in lung cancer therapy}

The possibility of using miRNAs for therapeutic purposes is one of the most interesting innovations in lung cancer therapy.

Recently, several studies on mice models of NSCLC paved the way for "miRNA replacement therapy" using exogenous delivery of let-7 to reduce tumor growth, showing a significative effect [220-221]. Similarly, let7 double stranded mimics were found able to inhibit cellular growth and migration as well to induce the cell cycle arrest of lung cancer cell lines in vitro [222]. Wiggins et al. used chemically synthesized miR-34a and a lipid-based delivery vehicle to reduce tumor growth in mouse models of NSCLC, confirming the hypothesis that the reintroduction of lost miRNAs in lung cancer cells reactivates the physiological inhibitory pathways involved in cancer control [223]. Interestingly, Trang et al. used synthetic tumor suppressors miR-34 and let-7 mimics complexed with a novel neutral lipid emulsion to target a KRAS-activated mouse model of NSCLC. Systemic delivery of these miRNA mimics led to a significant decrease in tumor burden, providing a confirmation of the promising role of miRNA mimics in lung cancer therapy [224]. Moreover, the observation that miR-145 is able to inhibit cell growth and the G1/S transition in transfection assays of A549 and $\mathrm{H} 23$ cells by targeting c-MYC, provide an innovative approach to the treatment of NSCLC [116]. Regarding the resistance to TKIs treatment that may affect several patients, miRNA delivery systems could play a key role in overcoming this resistance. Rai et al. used cationic liposomes loaded with miR-7-expressing plasmid to inhibit EGFR signaling causing a dramatic response in an EGFR-TKI-resistant lung cancer xenograft model [225]. Zhao et al., on the other hand, demonstrated that miR-34a mimics augment the sensitivity to erlotinib treatment in NSCLC and HCC cell lines, whether they were associated with primary or acquired resistance [226]. These findings are supported by the evidence that miR-34a targets MET and AXL, both involved in erlotinib resistance [227-228]. This data suggests a potential role of erlotinib-miR34a combination therapy, while a phase I clinical trial based on MRX34, a liposomal nanoparticle loaded with synthetic miR-34a mimics, was recently initiated [229].

On the other side, oncomir targeting therapies have been developed in recent years with promising results. "Antagomirs" and "LNA-antimiRs" represent new classes of antisense oligonucleotide with specific chemical modifications such as 2'-O methyl and Locked Nucleic Acid (LNA), which make them less susceptible to nuclease enzymes cleavage. These kinds of molecules could play a considerable role in miRNA silencing processes, thus suppressing those miRNAs with oncogenic properties [230-231]. Li et al. used an anti-miR-150 expression vector to suppress A549 cell proliferation by targeting miR-150. Tumor volume and weight were lower compared with the control group [232].

Elmen et al. showed that the administration of LNA-antimiR was able to silence miR-122 through the formation of stable heteroduplexes between the LNAantimiR and miR-122 in primate hepatocytes, confirming their potential role in miRNAs targeted therapies [231]. However, the ability to negatively regulate miRNAs levels had already been explored with success by Krützfeldt et al. in 2005. They showed that intravenous administration of antagomirs against miR-16, miR-122, miR-192 and miR194 resulted in a significant reduction of corresponding miRNA levels in different tissues and organs like liver, lung, kidney, heart, intestine, fat, skin, bone marrow, muscle, ovaries and adrenals [230].

Ebert et al. introduced another innovative method to induce loss of function in miRNAs by developing "miRNA-sponges", a novel class of competitive inhibitors of small RNAs in mammalian cells. Produced from transgenes within cells, sponge-miRNAs contain complementary binding sites to a miRNAs seed region, permitting a deep inhibition of whole classes of related miRNA which harbor the same seed site [233-234]. More recently, Obad et al. developed a further method to target the miRNA seed region, based on seed-targeting 8-mer locked nucleic acid (LNA) oligonucleotides, named "tiny LNAs" [235].

In conclusion, lipid-formulated mimics, antagomirs, miRNA sponges, virus vectors, locked nucleic acids (LNAs) as well as antisense oligonucleotides, all represent new promising therapeutic approaches based on the knowledge and manipulation of miRNAs, providing an important new tool in personalized therapy for lung cancer.

\section{Small interfering RNAs in lung cancer}

Small interfering RNAs (siRNA) represent a 1923 nucleotides class of small non-coding RNA involved in post-transcriptional gene silencing through the RISCmediated degradation mechanism of mRNA targets. Produced from long dsRNAs of exogenous or endogenous origin by a ribonuclease-III type endonuclease (DICER), they are made up of two partially complementary RNA single strands, named passenger strand and guide strand. SiRNAs are loaded into Argonaute 2 (Ago2) and the guide strand is subsequently incorporated in the RNA-induced silencing complex (RISC), leading to a sequence-specific degradation of complementary target mRNAs [27].

Since their discovery, siRNAs have shown a strong role in regulating gene expression, being able to silence 


\section{THERAPEUTIC SIRNAs}

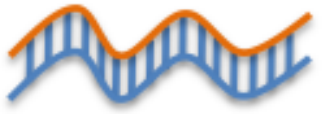

1. ASSEMBLY OF RISC

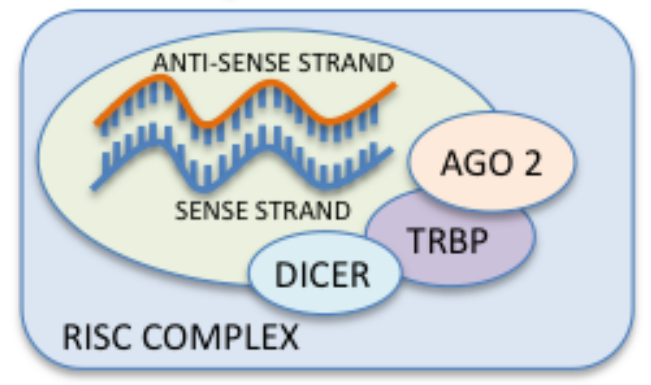

2. SIRNA UNWINDING

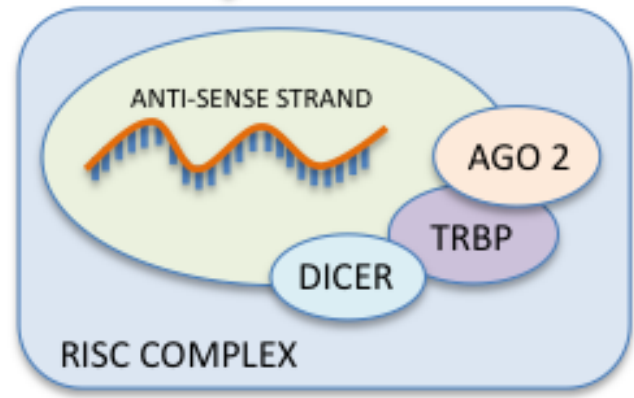

3. RECRUITMENT OF RISC TO TARGET MRNA

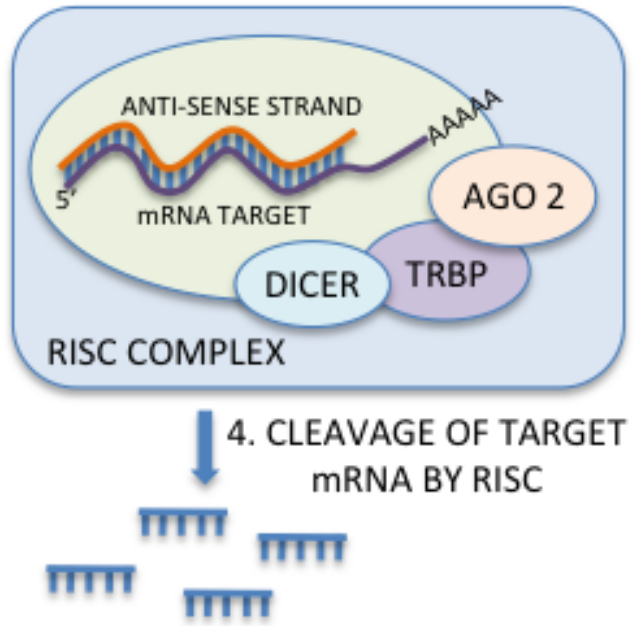

Figure 2: SiRNAs mechanism of action: The RNAinterference mediated knockdown of gene expression in mammalian cells is based on the introduction of synthetic double-stranded siRNAs or plasmid and viral vector systems expressing double-stranded short hairpin RNAs (shRNAs) that are processed by the cellular machinery into siRNAs. Once loaded into Argonaute 2 (Ago2), the guide strand is incorporated in the RNA-induced silencing complex (RISC), leading to a sequence-specific degradation of complementary target mRNAs. target genes in a highly specific manner. Because of these characteristics, siRNAs were immediately confirmed as indispensable tools for gene silencing experiments, and for this reason the possibility of their use in cancer therapy has been studied with promising results. The RNAinterference mediated knockdown of gene expression in mammalian cells is based on the introduction of synthetic double-stranded siRNAs or plasmid and viral vector systems expressing double-stranded short hairpin RNAs (shRNAs) that are processed by the cellular machinery into siRNAs (Figure 2).

Matsubara et al. evaluated the antitumor effects of mTOR-siRNA therapy in NSCLC cells, showing an increased level of apoptosis $(\mathrm{P}=0.016)$, as well as a deep inhibition of cell migration $(\mathrm{P}=0.0001)$ and proliferation $(\mathrm{P}=0.034)$ [236]. Furthermore, $\mathrm{Xu}$ et al. designed a specific small interfering RNA to target tissue factor (TF), a transmembrane glycoprotein recently discovered to be involved in lung cancer tumorigenesis. They demonstrated a dose-dependent downregulation of TF both in vitro and in vivo, leading to the inhibition of proliferation, invasion, metastasis, and to the induction of apoptosis, also resulting in the MAPK-ERK, PI3K/Akt and VEGF pathways suppression [237]. Moreover, $\mathrm{Wu}$ et al. identified CLEF1 as a potential target of siRNA-based therapy. CLEF1 is a post-transcriptional regulator of gene expression involved in different types of cancer, including lung cancer, and whose levels are significantly higher in neoplastic tissues. In this study, CELF1 silencing by siRNA lentiviralmediated transfection strongly reduced survival rates in lung cancer cells, likewise the number and size of lung cancer cell colonies [238].

In addition, many other possible therapeutic targets for treating lung cancer have recently been identified by siRNA technology. In detail, lentivirus-mediated siRNA knockdown of ZEB-1, NUPR1 and SGO-1 inhibits human NSCLC cell growth in vitro and in vivo [239-241].

Besides, in light of the role played by VEGF family and its receptors in the pathogenesis and especially in NSCLC target therapy, the possibility to silence the expression of these genes will surely result in a therapeutic evolution of extreme importance. In this regard Yang Y. et al. explored the antitumor efficacy of VEGF-shRNA on A549 cells in vitro and on A549 lung carcinoma xenografts in nude mice. VEGF-shRNA delayed tumor growth and significantly reduced tumor weight compared with controls $(\mathrm{P}<0.05)$, also showing a significant angiogenesis inhibition $(\mathrm{P}<0.01)$ and apoptosis induction $(\mathrm{P}<0.01)$ [242]. Feng Y. et al. developed a lentivirusmediated RNA interference to knockdown the expression of VEGF-C in A549 cells, demonstrating a suppression of cell growth, migration and invasion in vitro. Interestingly, these authors found that silencing VEGF-C also resulted in an overthrow of VEGFR-2, VEGFR-3, CXCR4, CCR7 signaling, and in a downregulation of Akt, ERK and p38 pathways [243]. A further study reported that the local 
injection of lentivirus-delivered shRNA against Livin (novel member of IAP family) into xenograft tumors derived from the lung adenocarcinoma cell line SPC-A-1 in $\mathrm{BALB} / \mathrm{C}$ nude mice, induced apoptosis and reduced tumor cell proliferation, tumor growth and weight. These findings supported the evidence that Livin shRNAmediated downregulation lead to G0/G1-phase cell cycle arrest, through cyclin D1 suppression, providing a new therapeutic approach for lung cancer therapy [244]. Li et al. evaluated the efficacy of the dual inhibition of FAK and EGFR by using plasmid vector-based RNA interference in A549 lung cancer cells, in vitro and in A549 subcutaneous xenograft mice model. They found that knockdown of FAK and EGFR expression in vitro significantly inhibited cell proliferation and induced cell apoptosis whereas mice treated with FAK and EGFR shRNA had smaller tumors $(\mathrm{P}<0.01)$ compared to controls, also resulting in a decreased microvessel density and cell proliferation [245]. In regards to EGFR gene silencing strategies, in 2005 Zhang et al. reported the potential role of a dsRNAmediated specific RNAi approach for silencing the EGFR in NSCLC cell lines in vitro and in vivo. For the first time, they demonstrated a significant silencing of an endogenous cellular gene and growth inhibition in vivo. In addition, these authors showed that this approach enhanced the chemosensitivity to cisplatin, paving the way for an original method to overcome cisplatin resistance that may develop because of EGFR pathway iperactivation [246]. More recently, Takahashi et al. developed an interesting way to inhibit the oncogenic EGFR alleles without affecting the normal EGFR allele, both in vivo and in vitro, through allele specific RNAi (ASP-RNAi) treatment. They confirmed that the specific inhibition of the EGFR mutated allele, represents a safe and effective progress for cancer therapy, also because ASP-RNAi treatment can suppress cancer cell proliferation and growth, regardless of sensitivity to EGFR-TKIs [247].

Furthermore, Chen et al. showed that the knockdown of T790M transcript by siRNAs, recovered the sensitivity of T790M mutant cells to TKIs, decreasing cell growth and inducing apoptosis of T790M mutant NSCLC cell line H1975 treated with TKIs, or cetuximab [248]. The same authors also described that the addition of EGFR siRNA to either TKIs or cetuximab additively enhanced growth inhibition, as well as the induction of apoptosis in all cell lines tested (HCC827, H292, H358, H1650, H1975), independent of their EGFR mutation status. Also in this case the greatest biological impact was observed when afatinib was combined with EGFR-specific siRNA [249].

Given the emerging role of KRAS mutations in lung cancer oncogenesis and progression, the chance of silencing this oncogene is of vital interest. In 2006, Zhang et al. evaluated the inhibitory effects of adenovirusmediated siRNA against mutant KRAS on NSCLCs, both in vivo and vitro, demonstrating a significant growth inhibition of lung adenocarcinomas [250]. Similarly, a more recent study found that mutant KRAS shRNAknockdown in NSCLC suppresses tumor growth also sensitizing tumor cells to p38 and EGFR inhibitors [251].

Another alternative approach to targeting KRASdriven lung cancers through RNA interference technology, is to identify and consequently silence the gene products whose inhibition may lead to cell death only in the presence of KRAS mutations. Among the potential synthetic lethal interactors investigated, the suppression of TANK-binding kinase 1 (TBK1) induces apoptosis only in KRAS mutated cancer cell lines via $\mathrm{NF \kappa B}$ pathway activation [252], while Syk and Ron kinases and integrin beta6 depletion were able to induce epithelialmesenchymal transformation (EMT) and apoptosis specifically in KRAS-dependent cells, both in lung and pancreatic cancer [253]. Remarkably, analogous findings were also reported in colorectal cancer cells harboring KRAS mutations. Here too, using a pool-based shRNA platform in a genome-wide screen, different KRAS synthetic lethal (RSL) genes were identified as possible therapeutic targets [254].

Finally, EZH2 silencing with siRNA has been proven to induce cell cycle G2/M arrest in human lung cancer cells, enhancing p53 and p21 expression and subsequently decreasing $\mathrm{Cdc} 2$ and cyclin $\mathrm{B} 1$ levels [255]. Another study explored the antitumor efficacy of siRNA-EZH2 in combination with radiotherapy in vitro and in vivo, and observed an increased inhibition of cell proliferation and cell cycle progression when the radiotherapy was associated with siRNA-EZH2 compared with radiotherapy alone [256]. Taken together, EZH2 gene silencing experiments showed promising results in vivo and in vitro, which in the near future could drive a targeted therapy based precisely on RNAi.

Despite the initial enthusiasm, several unsolved issues are still hindering the development of effective therapies based on gene silencing induced by RNAi: increase the stability of siRNA in the bloodstream, hit selective tumor tissue targets, increase the intracellular uptake and create a delivery system that ensures adequate dosing and distribution. These are currently the main challenges. To date, several types of delivery systems have been developed, viral vectors, liposome-based delivery systems, nanoparticle-based delivery systems, dendrimerbased delivery systems, carbon nanotube-based delivery systems, each of which have their own advantages and disadvantages [257]. Still, several of them are now in preclinical and clinical studies, with applications in various types of neoplasm, including NSCLC [258-260].

\section{Small nucleolar RNAs in lung cancer}

Small nucleolar RNAs consist of a 60-300 nucleotides long class of small non-coding RNAs involved in various and essential functions, including modification, maturation and maintenance of rRNA stability, in order 
to ensure a correct ribosomal biogenesis and function [261]. Currently they are classified into two categories, Box C/D and Box H/ACA, on the basis of the presence of a different consensus sequence [262]. Further evidence suggests that the $\mathrm{C} / \mathrm{D}$ box snoRNAs have a preminent role in the 2'-O-methylation of rRNAs whereas the H/ACA box snoRNAs are mainly involved in pseudouridylation of rRNAs [263].

Small nucleolar RNAs are located within introns of protein-coding genes transcribed by RNA polymerase II, as well as introns of long non-coding RNAs [261265]. C/D box snoRNA matures along either one of two different pathways. The first one involves the splicing of a pre-mRNA and subsequently the formation of a snoRNA-containing lariat, which is then linearized and cleaved by endonucleases and exonucleases, releasing the final mature snoRNA. The second maturation pathway is splicing-independent, and snoRNAs are excided from the intron regions of the pre-mRNAs by endonucleolytic cleavage [266].

However, in spite of the functions traditionally performed by the snoRNA, in 2011 Brameier et al. have demonstrated that some human snoRNAs act similarly to miRNAs. These sno-miRNAs originate from relatively short snoRNAs, showing several silencing features typical of miRNAs, appear involved in numerous cellular processes, including gene expression [267]. To date many studies have demonstrated the role the disruption of snoRNAs in several types of cancer, such as breast, prostate, B-cell lymphoma and recently acute promyelocytic leukemia [27]. Additionally, a growing body of evidence suggests a possible role of snoRNAs also in lung cancer.

Liao et al. profiled snoRNA expression signatures of early stage NSCLC by performing microarray analysis on surgical tissues, identifying six snoRNAs which, compared to noncancerous lung tissues, were overexpressed in tumor tissues. Interestingly, these authors demonstrated that snoRNAs were detectable in plasma, and three of them (SNORD33, SNORD66, SNORD76) showed higher plasma expressions in NSCLC patients compared with healthy control groups $(\mathrm{P}=0.01)$, yielding a $81.1 \%$ sensitivity and $95.8 \%$ specificity in discriminating NSCLC from cancer-free individuals and patients affected by COPD [268]. This data suggests that SNORD66, SNORD76 may act like oncogenes in lung cancer, as they are located in two of the most amplified chromosomal segments in solid neoplasm (19q13.3 and 1q25.1), while SNORD33 is encoded by chromosome 19q13.3 which contains different oncogenes involved in lung cancer and other solid tumors [269-272]. In a further study, Mei et al. found that snoRNA42 was overexpressed in NSCLC cells, and demonstrated that snoRNA42 knockdown decreased tumorigenicity in vitro and in vivo by inducing p53mediated apoptosis, whereas its upregulation promoted the cell growth of bronchial epitheliums [273]. Moreover, they observed an inverse correlation between SNORA42 expression in lung tumor tissue specimens and NSCLC patients survival [273].

Certainly, in the light of the new roles of snRNA in regulating gene expression and silencing processes, as well as cellular proliferation, differentiation and survival, their future use for therapeutic purposes appears highly topical. For instance, snoRA42 knockdown by siRNA has antiproliferative effects on NCSLC cells, leading to a diminished in vitro tumorigenicity. Similarly, snoRA42 knockdown was found to decrease in vivo tumorigenicity in both ectopic and orthotopic NSCLC xenograft mouse models [273].

However, as mentioned previously, some technical problems such as a definition of the appropriate dosage regimens and the creation of a suitable delivery system, limit the therapeutic use of siRNA.

Nevertheless, the study of the biological aspects of snoRNAs in cancer should be encouraged, and snoRNAs diagnostic and prognostic biomarkers should be developed, providing us with a new and useful tool for cancer detection and treatment.

\section{Piwi proteins associated RNAs in lung cancer}

Piwi proteins associated RNAs (piRNAs) represent the latest identified class of small non-coding RNA, and recent evidence highlighted their role in the preservation of genomic integrity [274].

Their name derives from their ability to interact only with PIWI proteins, a subfamily of Argonaute proteins which is involved in gene-silencing pathways, whereas siRNAs and miRNAs associate with AGO subfamily members [275]. PiRNAs are 24-32 nucleotides long ncRNAs, and are generated by a Dicer-independent mechanism [276].

Currently, both in Drosophila and in mammals, two different pathways have been described in piRNAs biogenesis, a primary pathway and a secondary pathway, the latter also termed the "ping pong" model.

In the primary pathway, piRNA are transcribed from pericentromeric or subtelomeric domains, which contain transposable DNA elements, or else from 3' UTRs of protein coding genes, and subsequently shortened into piRNA-like small RNAs [276]. The piRNAs are then exported to the cytoplasm where they undergo a maturation process which involves the putative RNA helicase Armitage (ARMI), the nuclease Zucchini (ZUC), and YB. Once 5' ends are formed, piRNAs are loaded onto PIWI proteins, then trimmed from the 3' and 29-O-methylated by HEN1/Pimet to produce mature piRNAs [277-278]. Unlike the primary pathway, which is shared both in germ and in somatic cells, the amplification "ping pong" cycle appears to be restricted to germ cells. In 2007, Brennecke et al. observed that AUB or PIWI associated with the antisense piRNA, cleaves the sense 
retrotransposon transcripts, leading to the creation of the $5^{\prime}$ ends of sense piRNA that in turn associates with AGO3 [276]. Then, AGO3-piRNA complex cleaves antisense retrotransposon transcripts making the $5^{\prime}$ end of antisense piRNAs that subsequently bind again to AUB or PIWI, establishing an amplification cycle which is mainly involved in targeting active transposons, thus safeguarding the genome [276, 279]. Nonetheless, recent studies on Drosophila demonstrated that piRNAs-PIWI complex is involved in gene silencing by binding its genomic target in euchromatin, and recruiting some important epigenetic regulators such as HP1a and the histone methyltransferase Su(var)3-9. Through a parallel mechanism, Piwi targets nascent transcripts via piRNA sequence complementarity [280].

Although most of the evidence about biogenesis and the function of piRNAs and PIWI proteins are related to studies done on Drosophila, it has been shown that this family of proteins is actually highly conserved across various species and organisms [281], and to date four PIWI proteins have been found in humans: PIWIL1/HIWI, PIWIL2/HILI, PIWIL3, and PIWIL4/HIWI2. However, in addition to the known functions performed in germ cells, it is now believed that piRNAs fulfill many other functions, as stem cell self-renewal, retrotransposon silencing, genetic and epigenetic regulation, and recently also the regulation of tumorigenesis [281]. Indeed, a growing body of evidence emphasizes the role of both piRNA and PIWI proteins in the biology of different types of cancer, including gastric, colon, lung, and breast cancer [282]. Besides, HIWI over-expression has also been found in cervical, pancreatic, colorectal, endometrial, esophageal, liver cancer, gliomas and seminomas [283-284].

Considering the role of HIWI genes in stem cell self-renewal and its overexpression in a variety of cancers, Liang et al. investigated the effect of HIWI gene silencing in lung cancer, hypothesizing that HIWI knockdown in lung cancer stem cells might exhibit anti-tumor effects. They constructed shRNA eukaryotic expression vector to target HIWI gene in vitro, revealing that growth of the lung cancer stem cells was inhibited and the proliferation rate was decreased following HIWI gene silencing [285].

More recently, Liang et al. developed an intravenous delivery system of shRNA plasmids against HIWI, showing a decreased number of lung cancer stem cells and a significant suppression of tumor growth in nude mice [286].

Certainly, the discovery of PIWI proteins associated RNAs has opened a new scenario in gene expression regulation, furthermore, their involvement in genomic stability, gene silencing, DNA repair and several tumorigenic processes, makes this new class of noncoding RNAs particularly interesting, and their potential clinical use, in terms of diagnostic, prognostic and predictive significance should be assessed.

\section{Long non-coding RNA in lung cancer}

In recent years, genome-wide transcriptomic analyses have clarified that the genome of mammals produces many long transcripts, also known as long non-coding RNAs (lnc-RNAs) [287]. LncRNAs are greater than 200 nucleotides long non-protein coding RNAs, mainly transcribed by RNA polymerase II from intergenic regions, promoter regions, or by transcriptional active pseudogenes, [288]. As protein coding genes do, so lncRNAs undergo post transcriptional processing, including 5'capping, alternative splicing, RNA editing, and polyadenylation [288, 5]. Based on their characteristics, IncRNAs are currently divided into five groups which include sense, antisense, bidirectional, intronic, and intergenic [289]. Recent studies have also shown that most IncRNAs displayed tissue-specific expression patterns [290].

When it comes to the various functions performed by IncRNA, the regulation of protein-coding genes expression is certainly the most important, however many others, such as epigenetic regulation, alternative splicing, RNA maturation and transport, protein synthesis, modulation of protein activity, alternation of protein localization, and the fact that they are precursors of small RNAs and tools for silencing miRNAs, have all been well documented (Figure 3) [291-292]. Additionally, lncRNAs are involved in the cell cycle regulation, survival, migration, and metabolism, and their dysregulation appears to contribute to the development and progression of human cancers (Table 4) [293-295].

H19 was the first lncRNA to be identified, and is expressed exclusively from the maternal allele. Its downregulation has been shown to decrease breast and lung cancer cell clonogenicity and anchorage-independent growth, whereas the loss of imprinting at the H19 locus, and resulting overexpression, has been described in many other cancers, including esophagus, colon, liver and bladder [296]. Interestingly, Lovejoy et al. determined that c-MYC, which is often overexpressed in lung cancer, directly binds to the $\mathrm{H} 19$ promoter and highly upregulates the transcription of the maternal H19 allele. These authors also found a strong association between c-MYC and H19 transcript levels, in both primary breast and lung cancer patient material [297].

MALAT1 (metastasis-associated lung adenocarcinoma transcript 1), also known as NEAT2 (nuclear-enriched abundant transcript 2), is the first lcnRNA associated with a strong metastatic potential and poor prognosis in patients affected by non-small cell lung cancer [298]. Currently, it is believed that the full length MALAT1 RNA is processed by RNaseP and RNaseZ to generate the small ncRNA mascRNA, which is subsequently exported to cytoplasm. Conversely, the large MALAT1 RNA is located in the nuclear speckles, where it is involved in alternative splicing [296]. 
Table 4: Examples of dysregulated long non coding RNAs in lung cancer

\begin{tabular}{|c|c|c|c|}
\hline $\begin{array}{l}\text { Long non- } \\
\text { coding RNA }\end{array}$ & $\begin{array}{l}\text { Genomic } \\
\text { location }\end{array}$ & Expression & Clinical implication \\
\hline MALAT1 & $11 \mathrm{q} 13.1$ & Upregulated & $\begin{array}{ll}\text { - } & \text { Poor prognosis } \\
\text { - } & \text { Shorter overall survival } \\
\text { - } & \text { Metastasis development }\end{array}$ \\
\hline HOTAIR & $12 q 13.13$ & Upregualated & $\begin{array}{l}\text { - } \text { Poor prognosis } \\
\text { - Advanced stage } \\
\text { - Lymph node metastasis } \\
\text { - Shorter disease free survival }\end{array}$ \\
\hline CCAT2 & $8 \mathrm{q} 24.21$ & Upregulated & $\begin{array}{l}\text { - } \quad \text { Poor prognosis } \\
\text { - } \quad \text { Lymph node metastasis }\end{array}$ \\
\hline BANCR & 9 & Downregulated & $\begin{array}{ll}\text { - } & \text { Poor prognosis } \\
\text { - } & \text { Advanced stage } \\
\text { - } & \text { Shorter overall survival } \\
\text { - } & \text { Metastasis development }\end{array}$ \\
\hline GAS5/GAS6-AS1 & $1 \mathrm{q} 25.1 / 13 \mathrm{q} 34$ & Downregulated & $\begin{array}{l}\text { - } \text { Poor prognosis } \\
\text { - Advanced stage } \\
\text { - } \quad \text { Lymph node metastasis } \\
\text { - }\end{array}$ \\
\hline ZXF1 & $10 \mathrm{q} 23.31$ & Upregulated & $\begin{array}{l}\text { - } \quad \text { Lymph node metastasis } \\
\text { - } \quad \text { Tumor pathological stage } \\
\text { - }\end{array}$ \\
\hline Sox2ot & $3 q 26.33$ & Upregulated & $\begin{array}{ll}\text { - } & \text { Poor prognosis } \\
\text { - } & \text { Metastasis development }\end{array}$ \\
\hline CARLo-5 & $8 \mathrm{q} 24.21$ & Upregulated & $\begin{array}{ll}\text { - } & \text { Poor prognosis } \\
\text { - } & \text { Metastasis development }\end{array}$ \\
\hline
\end{tabular}

Besides, alternative functions for MALAT1 were recently identified. Yang et al. demonstrated that it interacts with demethylated Pc2 (Polycomb 2 protein), thus controlling the relocalization of growth control genes between polycomb bodies and interchromatin granules, which are respectively silent and active gene expression sites [299].

As mentioned previously, MALAT1 high expression was at first identified as a prognosis factor for metastasis and survival in patients with early stage lung adenocarcinomas [298], however, also in squamous cell lung cancer MALAT1 overexpression is associated with a poor prognosis, correlating with an increased cell growth and colony formation of NSCLC cells in vitro [300].

Further studies evaluated the role of MALAT1 in the regulation of motility-related genes and metastasis phenotype in lung cancer cells, definitively establishing its role in the processes of cell migration and metastasis, also defining a more malignant neoplastic phenotype [301302].

The growing interest in non-invasive diagnostic 
techniques that may permit an early diagnosis, has led to the evaluation of lncRNAs in blood samples; for instance, HULC was found detectable in blood of patients with hepatocellular carcinoma [303], while PCA3 (prostate cancer gene 3) was found in the urine of prostate cancer patients [304]. Similarly, Weber et al. evaluated the potential role MALAT1 as a blood-based biomarker for NSCLC, finding a sensitivity of $56 \%$ and specificity of $96 \%$ in distinguishing cancer patients and cancer-free controls. The sensitivity to discriminate squamous cell carcinomas from controls was higher $(63 \%)$ than the sensitivity to discriminate adenocarcinomas from controls (48\%), and no impact of tumor stage, age, gender, and smoking status on MALAT1 levels was observed. Because of its low sensibility and high specificity, MALAT1 detection in blood samples might be used as a complementary biomarker within a panel to improve lung cancer diagnosis [305].

HOTAIR (Hox transcript antisense intergenic RNA) is a 2158 bp long lncRNA located at the HOXC locus on chromosome 12q13.13 [306], principally involved in epigenetic repression of target genes. Once spliced and polyadenilated, this lncRNA binds and recruits PRC2 and LSD1, redirecting the whole complex to HOXD locus on chromosome 2 , thus silencing a gene cluster involved in metastasis suppression through $\mathrm{H} 3 \mathrm{~K} 27$ methylation and H3K4 demethylation [295-296]. Actually, HOTAIR was also identified as a scaffold for the assembly of chromatinmodifying complexes [307].

To date, the negative prognostic influence of HOTAIR increased expression has been described in different types of cancer, such as melanoma, lung, colon, liver, pancreatic, and especially breast cancer [307-308].

As regards lung cancer, Liu et al. found that HOTAIR was highly expressed in NSCLC tissues and NSCLC cell lines. Moreover, they observed that high HOTAIR expression levels were associated with an advanced stage, lymph node metastasis, and poor prognosis, whereas patients with a lower expression of HOTAIR experienced a longer overall survival. Interestingly, this study also demonstrated that RNAimediated suppression of HOTAIR decreased the migration and invasion of NSCLC cells in vitro and blocked cell metastasis in vivo, therefore also suggesting a potential therapeutic role of lncRNA targeted therapies [309]. This data was confirmed and expanded upon by Nakagawa et al., who, by examining the expression of HOTAIR in 77 NSCLCs and 6 brain metastases by quantitative realtime RT-PCR, showed that high levels of expression of HOTAIR were associated with advanced stages of disease, lymph node metastasis and a shorter disease-free interval. It should be emphasized that in brain metastases HOTAIR levels were higher compared to primary tumor tissues [310].

Qui et al. analyzed the expression profile of a novel lncRNA, CCAT2 (colon cancer-associated transcript 2), in lung cancers, noticing that CCAT2 was significantly over-expressed in NSCLC tissues; in particular, they found that CCAT2 overexpression was associated with adenocarcinomas $(\mathrm{P}=0.033)$ but not with squamous cell carcinoma. Furthermore, in the same study it was shown that CCAT2 combined with CEA could predict lymph node metastasis, and siRNA silencing of CCTA2 resulted in the inhibition of the proliferation and invasion in NSCLC cell lines [311].

Another emerging lncRNA is the BRAF-activated non-coding RNA (BANCR), a 693-bp lncRNA located on chromosome 9, already found to be involved in melanoma cell migration [312]. Sun et al. evaluated BANCR expression in 113 NSCLC tissues and seven NSCLC cell lines, using quantitative polymerase chain reaction assay. They showed that BANCR was significantly downregulated in NSCLC samples, correlating to a more advanced stage of disease, development of widespread metastases, shorter overall survival, and poor prognosis (independent predictive value for TNM stage, $\mathrm{P}=0.038$ ) [313].

Recently, Shi X. et al. determined the expression pattern of the growth arrest-specific transcript 5 (GAS5) in 72 NSCLC specimens by qRT-PCR, assessing its biological role in the development and progression of NSCLC. This study also revealed that GAS5 expression is downregulated in NSCLC tissues compared to adjacent noncancerous tissues $(\mathrm{P}<0.05)$ and is still related to TNM stage $(\mathrm{P}<0.05)$ [171]. Therefore, GAS5 appears to act as a tumor suppressor in NSCLC, by inducing p53 mediated apoptosis and through E2F1 downregulation [314].

Similarly, lncRNA GAS6-AS1 (GAS6 antisense RNA 1) downregulation was found in NSCLC tissues compared with adjacent normal tissues $(\mathrm{P}<0.001)$, also negatively correlating with lymph node metastasis $(\mathrm{P}=$ $0.032)$ and advanced tumor node metastasis stage $(\mathrm{P}=$ 0.003). GAS6-AS1 expression was also an independent predictor for overall survival $(\mathrm{P}=0.036)$ [315].

Zhang et al. observed that the expression of long non-coding RNA ZXF1 was significantly upregulated in lung adenocarcinoma tissues compared with adjacent non-cancerous lung tissues $(\mathrm{P}<0.05)$ in 62 samples, and correlated with lymph node metastasis $(\mathrm{P}<0.05)$, tumor pathological stage $(\mathrm{P}<0.05)$, and shorter overall survival [316].

Furthermore, Hou $\mathrm{Z}$ et al. found that the expression level of Sox2ot (Sox2 overlapping transcript) was significantly higher in SCCs than that in adenocarcinoma and high Sox2ot expression levels predicted poor survival in lung cancer patients [317].

Lastly, Luo J et al. showed a significant upregulation of CARLo-5 (Cancer-associated region long non-coding RNA) in non small cell lung cancer tissues compared to their adjacent normal tissues, also experiencing a poorer prognosis in those patients with high CARLo-5 expression levels [318]. 
In summary, all of this data suggests that, in addition to their implication in the pathogenetic mechanisms of lung cancer, lncRNAs may also have a diagnostic and prognostic significance. Although further studies are required to confirm these findings, certainly the world of lncRNA is expected to play an increasingly important role in defining different aspects of this complex disease.

\section{CONCLUSION AND PERSPECTIVES}

The discovery of ncRNA has radically changed and improved our understanding of the molecular mechanisms behind the regulation of gene expression, also greatly enriching our knowledge of the molecular and cellular processes involved in cancer. The amazing versatility of some ncRNA, in particular miRNAs, to serve as diagnostic biomarkers, also with a clear prognostic and predictive value, is leading to the confirmation of ncRNAs as powerful clinical tools. In addition, the possibility of using this new class of RNA either as a therapeutic target and therapeutic means alongside the conventional therapies, justifies the amount of attention that the ncRNAs are receiving.

In this paper we reviewed the functional role of different classes of ncRNA in lung cancer, which represents the leading cause of cancer-related death worldwide. Lung cancer is a complex disease, and currently includes a wide variety of different diseases, each with its own clinical and biological features.

Therefore, it is clear that the study and evaluation of both coding and non-coding transcripts play an important role in defining the pathogenesis of lung cancer. It will enable us to develop a comprehensive clinical approach, also allowing for a further stratification of patients, and thus guarantee the development of targeted therapies based on single patient disease biology. Of course, to achieve these results some technical problems must be solved, like determining which are the best methods of delivering ncRNAs for therapeutic purposes (miRNAs/ siRNAs), identifying therapeutic dosage regimes, developing ncRNAs-based diagnostic panels (even across multiple classes of ncRNAs), confirming the prognostic and predictive significance of ncRNAs in large cohort studies and improving non-invasive diagnostic techniques that allow for the early detection of lung cancer.

In conclusion, the study of what has been described as "dark genomic matter" has led to a comprehensive overview of the human genome by shining light on corners of a universe as yet unexplored, but that looks extremely promising for the future applications it could well have to cancer research as well as other diseases.

\section{Conflict of Interest}

The authors declare no conflict of interest.

\section{REFERENCES}

1. Stein LD. Human genome: end of the beginning. Nature. 2004; 431(7011):915-916.

2. Ponting CP, Belgard TG. Transcribed dark matter: meaning or myth?. Hum Mol Genet. 2010;15 (19):162-168.

3. ENCODE Project Consortium, Birney E, Stamatoyannopoulos JA, Dutta A, Guigó R, Gingeras TR, Margulies EH, Weng Z, Snyder M, Dermitzakis ET, Thurman RE, Kuehn MS, Taylor CM, , Neph S, Koch CM, Asthana $\mathrm{S}$ et al. Identification and analysis of functional elements in $1 \%$ of the human genome by the ENCODE pilot project. Nature. 2007; 447(7146):799-816.

4. The ENCODE Project Consortium An integrated encyclopedia of DNA elements in the human genome. Nature. 2012(7414); 489:57-74.

5. Taft RJ, Pang KC, Mercer TR, Dinger M, Mattick JS: Non-coding RNAs: regulators of disease. J Pathol. 2010; 220(2):126-139.

6. Siegel R, Naishadham D, Jemal A. Cancer statistics, 2012. Cancer J. Clin. 2010; 62 (1):10-29.

7. Phizicky EM, Hopper. AK: tRNA biology charges to the front. Genes Dev. 2010; 24(17):1832-1860.

8. Hannan KM, Hannan RD, Rothblum LI. Transcription by RNA polymerase I. Front Biosci. 1998; 26 (3):376-398.

9. Stults DM, Killen MW, Pierce HH, Pierce AJ. Genomic architecture and inheritance of human ribosomal RNA gene clusters. Genome Res. 2008; 18(1):13-18.

10. Bartel DP. MicroRNAs: target recognition and regulatory functions. Cell. 2009; 136(2):215-233.

11. Carthew RW, Sontheimer EJ. Origins and Mechanisms of miRNAs and siRNAs. Cell. 2009; 136(4):642-655.

12. Kawaji H, Hayashizaki Y. Exploration of small RNAs. PLoS Genet. 2008; 4(1):e22.

13. Lin H. piRNAs in the germ line. Science. 2007; 316(5823):397

14. Kim VN, Han J, Siomi MC. Biogenesis of small RNAs in animals. Nat Rev Mol Cell Biol. 2009; 10(2):126-139.

15. Kiss T. Small nucleolar RNA-guided post-transcriptional modification of cellular RNAs. EMBO J. 2001; 20(14):3617-3622.

16. Filipowicz W, Pogacic V. Biogenesis of small nucleolar ribonucleoproteins. Curr Opin Cell Biol. 2002; 14(3):319327.

17. Holley CL and Topkara VK. An introduction to small noncoding RNAs: miRNA and snoRNA. Cardiovascular Drugs and Therapy. 2011; 25 (2):151-159.

18. Bortoluzzi S, Biasiolo M, and Bisognin A. microRNAoffset RNAs (moRNAs): by-product spectators or functional players?. Trends in Molecular Medicine. 2011; 17(9):473474.

19. Taft RJ, Kaplan CD, Simons C, and Mattick JS. Evolution, biogenesis and function of promoter-associated RNAs. Cell 
Cycle. 2009; 8(15):2332-2338.

20. Valadkhan S. snRNAs as the catalysts of pre-mRNA splicing. Curr Opin Chem Biol. 2005; 9(6):603-608.

21. Mercer TR, Dinger ME, and Mattick JS. Long noncoding RNAs: insights into functions. Nature Reviews Genetics. 2009; 10(3):155-159.

22. Katayama S1, Tomaru Y, Kasukawa T, Waki K, Nakanishi M, Nakamura M, Nishida H, Yap CC, Suzuki M, Kawai J, Suzuki H, Carninci P, Hayashizaki Y, et al. Antisense transcription in the mammalian transcriptome. Science. 2005; 309(5740):1564-1566.

23. Scaruffi P. The transcribed-ultraconserved regions: a novel class of long noncoding RNAs involved in cancer susceptibility. TheScientificWorldJournal. 2011; 11:340 352.

24. Poliseno L, Salmena L, Zhang J, Carver B, Haveman WJ, and Pandolfi PP. A coding-independent function of gene and pseudogene mRNAs regulates tumour biology. Nature. 2010; 465(7301):1033-1038.

25. Taft RJ, Glazov EA, Cloonan N, Simons C, Stephen S, Faulkner GJ, Lassmann T, Forrest AR, Grimmond SM, Schroder K, et al. Tiny RNAs associated with transcription start sites in animals. Nat Genet. 2009; 41(5):572-578.

26. Taft RJ, Simons C, Nahkuri S, Oey H, Korbie DJ, Mercer TR, Holst J, Ritchie W, Wong JJ, Rasko JE, Rokhsar DS, Degnan BM, Mattick JS. Nuclear-localized tiny RNAs are associated with transcription initiation and splice sites in metazoans. Nat Struct Mol Biol. 2010; 17(8):1030-1034.

27. Sana J, Faltejskova P, Svoboda M, Slaby O. Novel classes of non-coding RNAs and cancer. Journal of Translational Medicine. 2012; 10:103.

28. Shaw AT, Yeap BY, Mino-Kenudson M, Digumarthy SR, Costa DB, Heist RS, Solomon B, Stubbs H, Admane S, McDermott U, Settleman J, Kobayashi S, Mark EJ et al. Clinical features and outcome of patients with non-smallcell lung cancer who harbor EML4-ALK. J Clin Oncol. 2009; 27(26):4247-4253.

29. Bergethon K, Shaw AT, Ou SH, Katayama R, Lovly CM, McDonald NT, Massion PP, Siwak-Tapp C, Gonzalez A, Fang R, Mark EJ, Batten JM, Chen H et al. ROS1 rearrangements define a unique molecular class of lung cancers. J Clin Oncol. 2012; 30(8):863-870.

30. Sharma SV, Bell DW, Settleman J, Haber DA. Epidermal growth factor receptor mutations in lung cancer. Nat Rev Cancer. 2007; 7(3):169-181.

31. P-Y Lin, S-L Yu, and P-C Yang. MicroRNA in lung cancer. British Journal of Cancer. 2010; 103(8):1144-1148.

32. Griffiths-Jones S. miRBase: the microRNA sequence database. Methods Mol Biol. 2006; 342:129-138.

33. Krol J, Loedige I, Filipowicz W. The widespread regulation of microRNA biogenesis, function and decay. Nat Rev Genet. 2010; 11(9):597-610.

34. Ludwig Christian G Hinske, Pedro AF Galante, Winston P Kuo, Lucila Ohno-Machado. A potential role for intragenic
miRNAs on their hosts' interactome. BMC Genomics. 2010; 1(11):533.

35. Zeng Y, Cullen BR. Efficient processing of primary microRNA hairpins by Drosha requires flanking nonstructured RNA sequences. J. Biol. Chem. 2005; 280:27595-27603.

36. Zhang, X.; Zeng, Y. The terminal loop region controls microRNA processing by Drosha and Dicer. Nucleic Acids Res. 2010; 38(21):7689-7697.

37. Leigh-Ann MacFarlane and Paul R. Murphy. MicroRNA: Biogenesis, Function and Role in Cancer. Current Genomics. 2010; 11(7):537-561.

38. Denli AM, Tops BB, Plasterk RH, Ketting RF, Hannon GJ. Processing of primary microRNAs by the Microprocessor complex. Nature. 2004; 432(7014):231-235.

39. Han J, Lee Y, Yeom, KH, Nam, JW, Heo I, Rhee JK, Sohn SY, Cho Y, Zhang BT, Kim VN. Molecular basis for the recognition of primary microRNAs by the Drosha-DGCR8 complex. Cell. 2006; 125(5):887-901.

40. Gregory RI, Shiekhattar R. MicroRNA biogenesis and cancer. Cancer Res. 2005; 65(9):3509-3512.

41. Jakub O. Westholm and Eric C. Lai. Mirtrons: microRNA biogenesis via splicing Biochimie. 2011; 93(11):18971904.

42. Haase AD, Jaskiewicz L, Zhang H, Lainé S, Sack R, Gatignol A, Filipowicz W. TRBP, a regulator of cellular PKR and HIV-1 virus expression, interacts with Dicer and functions in RNA silencing. EMBO Rep. 2005; 6(10):961967.

43. Lee Y, Hur I, Park SY, Kim YK, Suh MR, Kim VN. The role of PACT in the RNA silencing pathway. EMBO J. 2006; 8;25(3):522-532.

44. Diederichs S, Haber DA. Dual role for argonautes in microRNA processing and posttranscriptional regulation of microRNA expression Cell. 2007; 131(6):1097-108.

45. Cifuentes D, Xue H, Taylor DW, Patnode H, Mishima Y, Cheloufi S, Ma E, Mane S, Hannon GJ, Lawson ND, Wolfe SA, Giraldez AJ. A novel miRNA processing pathway independent of Dicer requires Argonaute2 catalytic activity. Science. 2010; 328(5986):1694-1698.

46. Meister G, Landthaler M, Patkaniowska A, Dorsett Y, Teng G, Tuschl T. Human Argonaute2 mediates RNA cleavage targeted by miRNAs and siRNAs. Mol Cell. 2004; 15(2):185-197.

47. Song JJ, Smith SK, Hannon GJ, Joshua-Tor L. Crystal structure of Argonaute and its implications for RISC slicer activity. Science. 2004; 305(5689):1434-1437.

48. O'Carroll D, Mecklenbrauker I, Das PP, Santana A, Koenig U, Enright AJ, Miska EA, Tarakhovsky A. A Slicerindependent role for Argonaute 2 in hematopoiesis and the microRNA pathway. Genes Dev. 2007;21(16):1999-2004.

49. Brennecke J, Stark A, Russell RB, Cohen SM. Principles of microRNA-target recognition. PLoS Biol. 2005;3(3):e85.

50. Valencia-Sanchez MA, Liu J, Hannon GJ, Parker R. Control 
of translation and mRNA degradation by miRNAs and siRNAs. Genes Dev. 2006;20(5):515-24.

51. Coller J, Parker R. General translational repression by activators of mRNA decapping. Cell. 2005; 122(6):875-886.

52. Pillai RS, Bhattacharyya SN, Artus CG, Zoller T, Cougot N, Basyuk E, Bertrand E, Filipowicz W. Inhibition of translational initiation by Let-7 MicroRNA in human cells. Science. 2005; 309(5740):1573-1576.

53. Pillai RS, Artus CG, Filipowicz W. Tethering of human Ago proteins to mRNA mimics the miRNA-mediated repression of protein synthesis. RNA. 2004; 10(10):1518-1525.

54. Coller JM, Tucker M, Sheth U, Valencia-Sanchez MA, Parker R. The DEAD box helicase, Dhh1p, functions in mRNA decapping and interacts with both the decapping and deadenylase complexes. RNA. 2001;7(12):1717-1727.

55. Andrei MA, Ingelfinger $D$, Heintzmann $R$, Achsel $T$, Rivera-Pomar R, Lührmann R. A role for eIF4E and eIF4Etransporter in targeting mRNPs to mammalian processing bodies. RNA. 2005;11(5):717-727.

56. Chu CY, Rana TM. Translation repression in human cells by microRNA-induced gene silencing requires $\mathrm{RCK} / \mathrm{p} 54$. PLoS Biol. 2006;4(7):e210.

57. Jakymiw A, Pauley KM, Li S, Ikeda K, Lian S, Eystathioy T, Satoh M, Fritzler MJ, Chan EK. The role of GW/Pbodies in RNA processing and silencing. J Cell Sci. 2007; 120 (8):1317-1323.

58. Kahvejian A, Svitkin YV, Sukarieh R, M'Boutchou MN, Sonenberg N. Mammalian poly(A)-binding protein is a eukaryotic translation initiation factor, which acts via multiple mechanisms. Genes Dev. 2005;19(1):104-113.

59. Chivukula RR, Mendell JT. Circular reasoning: microRNAs and cell-cycle control. Trends Biochem Sci. 2008;33(10):474-481.

60. Ji Qi and David Mu. MicroRNAs and lung cancers: from pathogenesis to clinical implications. Front Med . 2012; 6(2):134-155.

61. Volinia S, Calin GA, Liu CG, Ambs S, Cimmino A, Petrocca F, Visone R, Iorio M, Roldo C, Ferracin M, Prueitt RL, Yanaihara N, Lanza G, et al. A microRNA expression signature of human solid tumors defines cancer gene targets. Proc Natl Acad Sci U S A. 2006; 103(7):2257-2261.

62. Seike M, Goto A, Okano T, Bowman ED, Schetter AJ, Horikawa I, Mathe EA, Jen J, Yang P, Sugimura H, Gemma A, Kudoh S, Croce CM, Harris CC. MiR-21 is an EGFRregulated antiapoptotic factor in lung cancer in neversmokers. Proc Natl Acad Sci U S A. 2009; 106(29):1208512090 .

63. Hatley ME, Patrick DM, Garcia MR, Richardson JA, Bassel-Duby R, van Rooij E, Olson EN. Modulation of K-Ras-dependent lung tumorigenesis by MicroRNA-21. Cancer Cell. 2010; 18(3): 282-293.

64. Frezzetti D, De Menna M, Zoppoli P, Guerra C, Ferraro A, Bello AM, De Luca P, Calabrese C, Fusco A, Ceccarelli M, Zollo M, Barbacid M, Di Lauro R, De Vita G. Upregulation of miR-21 by Ras in vivo and its role in tumor growth. Oncogene. 201; 30(3):275-286.

65. Pan X, Wang ZX, and Wang R. MicroRNA-21 A novel therapeutic target in human cancer Cancer Biology \& Therapy. 2010;10(12):1224-1232.

66. Hayashita Y, Osada H, Tatematsu Y, Yamada H, Yanagisawa K, Tomida S, Yatabe Y, Kawahara K, Sekido Y, Takahashi T. A polycistronic microRNA cluster, miR-17-92, is overexpressed in human lung cancers and enhances cell proliferation. Cancer Res. 2005; 65(21):9628-9632.

67. Olive V, Jiang I, He L. mir-17-92, a cluster of miRNAs in the midst of the cancer network. Int J Biochem Cell Biol. 2010;42(8):1348-54.

68. Taguchi A, Yanagisawa K, Tanaka M, Cao K, Matsuyama Y, Goto H, Takahashi T. Identification of hypoxia-inducible factor-1 alpha as a novel target for miR-17-92 microRNA cluster. Cancer Res. 2008; 15;68(14):5540-5545.

69. Koshiji M, Kageyama Y, Pete EA, Horikawa I, Barrett JC, Huang LE. HIF-1alpha induces cell cycle arrest by functionally counteracting Myc. EMBO J. 2004;23(9):19491956.

70. Goda N, Ryan HE, Khadivi B, McNulty W, Rickert RC, Johnson RS. Hypoxia-inducible factor 1a is essential for cell cycle arrest during hypoxia. Mol Cell Biol. 2003;23(1):359-369.

71. Zhang H, Gao P, Fukuda R, et al. HIF-1 inhibits mitochondrial biogenesis and cellular respiration in VHLdeficient renal cell carcinoma by repression of C-MYC activity. Cancer Cell. 2007;11(5):407-420.

72. O'Donnell KA1, Wentzel EA, Zeller KI, Dang CV, Mendell JT. c-Myc-regulated microRNAs modulate E2F1 expression. Nature. 2005; 435(7043):839-843.

73. Woods K, Thomson JM, Hammond SM: Direct regulation of an oncogenic micro-RNA cluster by E2F transcription factors. J Biol Chem. 2007; 282(4):2130-2134.

74. Garofalo M, Quintavalle C, Di Leva G, Zanca C, Romano G, Taccioli C, Liu CG, Croce CM, Condorelli G. MicroRNA signatures of TRAIL resistance in human nonsmall cell lung cancer. Oncogene. 2008; 27(27):3845-3855.

75. Garofalo M, Di Leva G, Romano G, Nuovo G, Suh SS, Ngankeu A, Taccioli C, Pichiorri F, Alder H, Secchiero P, Gasparini P, Gonelli A, Costinean S, et al. miR-221\&222 regulate TRAIL resistance and enhance tumorigenicity through PTEN and TIMP3 downregulation. Cancer Cell. 2009; 16(6):498-509.

76. Zhang C, Zhang J, Zhang A, Wang Y, Han L, You Y, Pu P, Kang C. PUMA is a novel target of miR-221/222 in human epithelial cancers. Int J Oncol. 2010; 37(6):1621-1626.

77. Garofalo M, Quintavalle C, Romano G, Croce CM, Condorelli G. miR221/222 in cancer: their role in tumor progression and response to therapy. Curr Mol Med. 2012; 12(1):27-33.

78. Galardi S, Mercatelli N, Giorda E, Massalini S, Frajese GV, Ciafre SA, Farace MG. miR-221 and miR-222 expression 
affects the proliferation potential of human prostate carcinoma cell lines by targeting p27Kip1. J Biol Chem. 2007; 282(32):23716-23724.

79. Higgs G, Slack F. The multiple roles of microRNA-155 in oncogenesis. J Clin Bioinforma. 2013;3(1):17.

80. Gironella M, Seux M, Xie MJ, Cano C, Tomasini R, Gommeaux J, Garcia S, Nowak J, Yeung ML, Jeang KT, Chaix A, Fazli L, Motoo Y, et al. Tumor protein 53-induced nuclear protein 1 expression is repressed by miR-155, and its restoration inhibits pancreatic tumor development. Proc Natl Acad Sci U S A. 2007;104(41):16170-16175.

81. Ovcharenko D1, Kelnar K, Johnson C, Leng N, Brown D. Genome-scale microRNA and small interfering RNA screens identify small RNA modulators of TRAIL-induced apoptosis pathway. Cancer Res. 2007;67(22):10782-10788.

82. Jiang S, Zhang HW, Lu MH, He XH, Li Y, Gu H, Liu MF, Wang ED. MicroRNA-155 functions as an OncomiR in breast cancer by targeting the suppressor of cytokine signaling 1 gene. Cancer Res. 2010;70(8):3119-3127.

83. Yamanaka Y, Tagawa $\mathrm{H}$, Takahashi $\mathrm{N}$, Watanabe A, Guo YM, Iwamoto K, Yamashita J, Saitoh H, Kameoka Y, Shimizu N, Ichinohasama R, Sawada K. Aberrant overexpression of microRNAs activate AKT signaling via down-regulation of tumor suppressors in natural killer-cell lymphoma/leukemia. Blood. 2009;114(15):3265-3275.

84. Kong W, Yang H, He L, Zhao JJ, Coppola D, Dalton WS, Cheng JQ. MicroRNA-155 is regulated by the transforming growth factor beta/Smad pathway and contributes to epithelial cell plasticity by targeting RhoA. Mol Cell Biol. 2008;28(22):6773-6784.

85. Liu L, Jiang $Y$, Zhang $H$, Greenlee AR, Han Z. Overexpressed miR-494 down-regulates PTEN gene expression in cells transformed by anti-benzo(a)pyrenetrans-7,8-dihydrodiol-9,10-epoxide. Life Sci. 2010; 86(56):192-198.

86. Romano G, Acunzo M, Garofalo M, Di Leva G, Cascione L, Zanca C, Bolon B, Condorelli G, Croce CM. MiR-494 is regulated by ERK1/2 and modulates TRAIL-induced apoptosis in non-small-cell lung cancer through BIM downregulation. Proc Natl Acad Sci U S A. 2012; 109(41):1657016575.

87. Wang Q, Li DC, Li ZF, Liu CX, Xiao YM, Zhang B, Li XD, Zhao J, Chen LP, Xing XM, Tang SF, Lin YC, Lai YD, et al.. Upregulation of miR-27a contributes to the malignant transformation of human bronchial epithelial cells induced by SV40 small T antigen. Oncogene. 2011; 30(36):38753886.

88. Arora S, Ranade AR, Tran NL, Nasser S, Sridhar S, Korn RL, Ross JT, Dhruv H, Foss KM, Sibenaller Z, Ryken T, Gotway MB, Kim S, Weiss GJ. MicroRNA-328 is associated with (nonsmall) cell lung cancer (NSCLC) brain metastasis and mediates NSCLC migration. Int J Cancer. 2011; 129(11):2621-2631.

89. Wang PY, Li YJ, Zhang S, Li ZL, Yue Z, Xie N, Xie SY. Regulating A549 cells growth by ASO inhibiting miRNA expression. Mol Cell Biochem. 2010; 339(1-2):163-171.

90. Cao G, Huang B, Liu Z, Zhang J, Xu H, Xia W, Li J, Li S, Chen L, Ding H, Zhao Q, Fan M, Shen B, Shao N. Intronic miR-301 feedback regulates its host gene, ska2, in A549 cells by targeting MEOX2 to affect ERK/CREB pathways. Biochem Biophys Res Commun. 2010; 396(4):978-982.

91. Liu L, Nie J, Chen L, Dong G, Du X, Wu X, Tang Y, Han W. The oncogenic role of microRNA-130a/301a/454 in human colorectal cancer via targeting Smad4 expression. PLoS One. 2013;8(2):e55532.

92. Liu Y1, Li M, Zhang G, Pang Z. MicroRNA-10b overexpression promotes non-small cell lung cancer cell proliferation and invasion Eur J Med Res. 2013;18(41).

93. . Du L, Schageman JJ, Subauste MC, Saber B, Hammond SM, Prudkin L, Wistuba, Ji L, Roth JA, Minna JD, Pertsemlidis A. miR-93, miR-98, and miR-197 regulate expression of tumor suppressor gene FUS1. Mol Cancer Res. 2009; 7(8):1234-1243.

94. Prudkin L, Behrens C, Liu DD, Zhou X, Ozburn NC, Bekele BN, Minna JD, Moran C, Roth JA, Ji L, Wistuba. Loss and reduction of FUS1 protein expression is a frequent phenomenon in the pathogenesis of lung cancer. Clin Cancer Res. 2008; 14(1):41-47.

95. Lin Ji, PhD and Jack A. Roth, MD Tumor Suppressor FUS1 Signaling Pathway. J Thorac Oncol . 2008; 3(4):327-330.

96. Takamizawa J, Konishi H, Yanagisawa K, Tomida S, Osada H, Endoh H, Harano T, Yatabe Y,Nagino M, Nimura Y, Mitsudomi T, Takahashi T. Reduced expression of the let-7 microRNAs in human lung cancers in association with shortened postoperative survival. Cancer Res. 2004; 64(11):3753-3756.

97. Roush S, Slack FJ. The let-7 family of microRNAs. Trends Cell Biol. 2008; 18(10):505-516.

98. Johnson SM, Grosshans H, Shingara J, Byrom M, Jarvis R, Cheng A, Labourier E, Reinert KL, Brown D, Slack FJ. RAS is regulated by the let-7 microRNA family. Cell 2005;120(5): 635-647.

99. Johnson CD, Esquela-Kerscher A, Stefani G, Byrom M, Kelnar K, Ovcharenko D, Wilson M, Wang X, Shelton J, Shingara J, Chin L, Brown D, Slack FJ. The let-7 microRNA represses cell proliferation pathways in human cells. Cancer Res. 2007;67(16):7713-7722.

100. Leidinger P, Keller A, Meese E. MicroRNAs - Important Molecules in Lung Cancer Research. Front Genet. 2012; 2(104).

101. Chin LJ, Ratner E, Leng S, Zhai R, Nallur S, Babar I, Muller RU, Straka E, Su L, Burki EA, Crowell RE, Patel R, Kulkarni $\mathrm{T}$ et al. A SNP in a let-7 microRNA complementary site in the KRAS 3' untranslated region increases non-small cell lung cancer risk. Cancer Res. 2008;68(20):8535-8540.

102. Nelson HH, Christensen BC, Plaza SL, Wiencke JK, Marsit CM, and Kelsey KT. KRAS mutation, KRASLCS6 polymorphism, and non-small cell lung cancer Lung 
Cancer. 2010 July; 69(1):51-53.

103. Sarhadi VK, Wikman H, Salmenkivi K, Kuosma E, Sioris T, Salo, J, Karjalainen A. Knuutila, S, Anttila S. Increased expression of high mobility group A proteins in lung cancer. J. Pathol. 2006; 209(2):206-212.

104. Mayr C, Hemann MT, Bartel DP. Disrupting the pairing between let-7 and Hmga2 enhances oncogenic transformation. Science. 2007; 315(5818):1576-1579.

105. Lee YS, Dutta A. The tumor suppressor microRNA let7 represses the HMGA2 oncogene. Genes Dev. 2007; 21(9):1025-1030.

106. Zhan M, Qu Q, Wang G, Liu YZ, Tan SL, Lou XY, Yu J, Zhou HH.Let-7c Inhibits NSCLC Cell Proliferation by Targeting HOXA1. Asian Pacific J Cancer Prev; 14(1):387392.

107. Xin M, Small EM, Sutherland LB, Qi X, McAnally J, Plato CF, Richardson JA, Bassel-Duby R, Olson EN. MicroRNAs miR-143 and miR-145 modulate cytoskeletal dynamics and responsiveness of smooth muscle cells to injury. Genes Dev. 2009; 23(18):2166-2178.

108. Akao Y, Nakagawa Y, Kitade Y, Kinoshita T, Naoe T. Downregulation of microRNAs-143 and -145 in B-cell malignancies. Cancer Sci. 2007; 98(12):1914-1920.

109. Ichimi T, Enokida H, Okuno Y, Kunimoto R, Chiyomaru T, Kawamoto K, Kawahara K, Toki K, Kawakami K, Nishiyama K, Tsujimoto G, Nakagawa M, Seki N. Identification of novel microRNA targets based on microRNA signatures in bladder cancer. Int J Cancer. 2009; 125(2): 345-352.

110. Iorio MV, Ferracin M, Liu CG, Veronese A, Spizzo R, Sabbioni S, Magri E, Pedriali M, Fabbri M, Campiglio M, Menard S, Palazzo JP, Rosenberg A, Musiani P, Volinia S, Nenci I, Calin GA, Querzoli P, Negrini M, Croce CM. MicroRNA gene expression deregulation in human breast cancer. Cancer Res. 2005; 65(16):7065-7070.

111. Suh SO, Chen Y, Zaman MS, Hirata H, Yamamura S, Shahryari V, Liu J, Tabatabai ZL, Kakar S, Deng G, Tanaka Y, Dahiya R. MicroRNA-145 is regulated by DNA methylation and p53 gene mutation in prostate cancer. Carcinogenesis. 2011; 32(5):772-778.

112. Takagi T, Iio A, Nakagawa Y, Naoe T, Tanigawa N, Akao Y. Decreased expression of microRNA-143 and -145 in human gastric cancers. Oncology. 2009; 77(1):12-21.

113. Wang X, Tang S, Le SY, Lu R, Rader JS, Meyers C, Zheng ZM. Aberrant expression of oncogenic and tumorsuppressive microRNAs in cervical cancer is required for cancer cell growth. PLoS One. 2008; 3(7):e2557.

114. Liu X, Sempere LF, Galimberti F, Freemantle SJ, Black C, Dragnev KH, Ma Y, Fiering S, Memoli V, Li H, DiRenzo J, Korc M, Cole CN, Bak M, Kauppinen S, Dmitrovsky E. Uncovering growth-suppressive MicroRNAs in lung cancer. Clin Cancer Res. 2009; 15(4):1177-1783.

115. Cho WC, Chow AS, Au JS. MiR-145 inhibits cell proliferation of human lung adenocarcinoma by targeting
EGFR and NUDT1. RNA Biol. 2011; 8(1):125-131.

116. Chen Z, Zeng H, Guo Y, Liu P, Pan H, Deng A, Hu J. miRNA-145 inhibits non-small cell lung cancer cell proliferation by targeting c-Myc. J Exp Clin Cancer Res. 2010; 29(151).

117. Yin R, Zhang S, Wu Y, Fan X, Jiang F, Zhang Z, Feng $\mathrm{D}$, Guo $\mathrm{X}, \mathrm{Xu}$ L. microRNA-145 suppresses lung adenocarcinoma-initiating cell proliferation by targeting OCT4. Oncol Rep. 2011; 25(6):1747-1754.

118. Ma Q, Jiang Q, Pu Q, Zhang X, Yang W, Wang Y, Ye S, Wu S, Zhong G, Ren J, Zhang Y, Liu L, Zhu W. MicroRNA-143 inhibits migration and invasion of human non-small-cell lung cancer and its relative mechanism. Int J Biol Sci. 2013; 9(7):680-92.

119. Gotte M, Yip GW. Heparanase, hyaluronan, and CD44 in cancers: a breast carcinoma perspective. Cancer Res. 2006; 66:10233-10237.

120. Chang TC, Wentzel EA, Kent OA, Ramachandran K, Mullendore M, Lee KH, Feldmann G, Yamakuchi M, Ferlito M, Lowenstein CJ, Arking DE, Beer MA, Maitra A, Mendell JT. Transactivation of miR-34a by p53 broadly influences gene expression and promotes apoptosis. Mol Cell. 2007; 26(5):745-752.

121. Tarasov V, Jung P, Verdoodt B, Lodygin D, Epanchintsev A, Menssen A, Meister G, Hermeking H. Differential regulation of microRNAs by 553 revealed by massively parallel sequencing: miR-34a is a p53 target that induces apoptosis and G1-arrest. Cell Cycle. 2007; 6(13):15861593.

122. Lize M, Klimke A, Dobbelstein M. MicroRNA-449 in cell fate determination. Cell Cycle. 2011; 10(17):2874-2882.

123. Mudduluru G, Ceppi P, Kumarswamy R, Scagliotti GV, Papotti M, Allgayer H. Regulation of Axl receptor tyrosine kinase expression by miR-34a and miR-199a/b in solid cancer. Oncogene. 2011; 30(25):2888-2899.

124. Kim NH, Kim HS, Li XY, Lee I, Choi HS, Kang SE, Cha SY, Ryu JK, Yoon D, Fearon ER, Rowe RG, Lee S, Maher CA, Weiss SJ, Yook JI. A p53/miRNA-34 axis regulates Snaill-dependent cancer cell epithelial-mesenchymal transition. J Cell Biol. 2011; 195(3):417-433.

125. Muth M, Hussein K, Jacobi C, Kreipe H, Bock O. Hypoxiainduced down-regulation ofmicroRNA-449a/b impairs control over targeted SERPINE1 (PAI-1) mRNA - a mechanism involved in SERPINE1 (PAI-1) overexpression. J Transl Med. 2011; 9:24.

126. Garofalo M, Jeon YJ, Nuovo GJ, Middleton J, Secchiero P, Joshi P, Alder H, Nazaryan N, Di Leva G, Romano G, Crawford M, Nana-Sinkam P, Croce CM. MiR$34 a / c-D e p e n d e n t$ PDGFR- $\alpha / \beta$ Downregulation Inhibits Tumorigenesis and Enhances TRAIL-Induced Apoptosis in Lung Cancer. PLoS One. 2013; 8(6):e67581.

127. Calin GA, Dumitru CD, Shimizu M, Bichi R, Zupo S, Noch E, Aldler H, Rattan S, Keating M, Rai K, Rassenti L, Kipps T, Negrini M, et al. Frequent deletions and down-regulation 
of micro- RNA genes miR15 and miR16 at 13q14 in chronic lymphocytic leukemia. Proc Natl Acad Sci U S A. 2002; 99(24):15524-15529.

128. Aqeilan RI, Calin GA, Croce CM. miR-15a and miR-16-1 in cancer: discovery, function and future perspectives. Cell Death Differ. 2010; 17(2):215-220.

129. Ofir M, Hacohen D, Ginsberg D. MiR-15 and miR-16 are direct transcriptional targets of E2F1 that limit E2F-induced proliferation by targeting cyclin E. Mol Cancer Res. 2011; 9(4):440-447.

130. Bandi N, Vassella E. miR-34a and miR-15a/16 are coregulated in non-small cell lung cancer and control cell cycle progression in a synergistic and Rb-dependent manner. Mol Cancer. 2011; 10:55.

131. Yanaihara N, Caplen N, Bowman E, Seike M, Kumamoto K, Yi M, Stephens RM, Okamoto A, Yokota J, Tanaka T, Calin GA, Liu CG, Croce CM, Harris CC. Unique microRNA molecular profiles in lung cancer diagnosis and prognosis. Cancer Cell. 2006; 9(3):189-198.

132. Fabbri M, Garzon R, Cimmino A, Liu Z, Zanesi N, Callegari E, Liu S, Alder H, Costinean S, Fernandez-Cymering C, Volinia S, Guler G, et al. MicroRNA-29 family reverts aberrant methylation in lung cancer by targeting DNA methyltransferases 3A and 3B. Proc Natl Acad Sci U S A. 2007; 104(40):15805-15810.

133. Gebeshuber CA, Zatloukal K, Martinez J. miR-29a suppresses tristetraprolin, which is a regulator of epithelial polarity and metastasis. EMBO Rep. 2009; 10(4):400-405.

134. Mott JL, Kobayashi S, Bronk SF, Gores GJ. mir-29 regulates Mcl-1 protein expression and apoptosis. Oncogene. 2007; 26(42):6133-6140.

135. Gregory PA, Bert AG, Paterson EL, Barry SC, Tsykin A, Farshid G, Vadas MA, Khew-Goodall Y, Goodall GJ. The miR-200 family and miR-205 regulate epithelial to mesenchymal transition by targeting ZEB1 and SIP1. Nat Cell Biol. 2008; 10(5):593-601.

136. Hurteau GJ, Carlson JA, Spivack SD, Brock GJ. Overexpression of the microRNA hsa-miR-200c leads to reduced expression of transcription factor 8 and increased expression of E-cadherin. Cancer Res. 2007; 67(17):79727976.

137. Roybal JD, Zang Y, Ahn YH, Yang Y, Gibbons DL, Baird BN, Alvarez C, Thilaganathan N, Liu DD, Saintigny P, Heymach JV, Creighton CJ, Kurie JM. miR-200 Inhibits lung adenocarcinoma cell invasion and metastasis by targeting Flt1/VEGFR1. Mol Cancer Res. 2011; 9(1):25-35.

138. Yang Y, Ahn YH, Gibbons DL, Zang Y, Lin W, Thilaganathan N, Alvarez CA, Moreira DC, Creighton CJ, Gregory PA, Goodall GJ, Kurie JM. The Notch ligand Jagged 2 promotes lung adenocarcinoma metastasis through a miR-200-dependent pathway in mice. J Clin Invest. 2011; 121(4):1373-1385.

139. Korpal M, Ell BJ, Buffa FM, Ibrahim T, Blanco MA, CeliaTerrassa T, Mercatali L, Khan Z, Goodarzi H, Hua Y, Wei
Y, Hu G, Garcia BA, et al. Direct targeting of Sec23a by miR-200s influences cancer cell secretome and promotes metastatic colonization. Nat Med. 2011; 17(9):1101-1108.

140. Kopp F, Wagner E, Roidl A. The proto-oncogene KRAS is targeted by miR-200c. Oncotarget. 2014; 5(1):185-195.

141. Meister J, Schmidt MH. miR-126 and miR-126*: new players in cancer. ScientificWorldJournal. 2010; 10:20902100.

142. Crawford M, Brawner E, Batte K, Yu L, Hunter MG, Otterson GA, Nuovo G, Marsh CB, Nana-Sinkam SP. MicroRNA-126 inhibits invasion in non-small cell lung carcinoma cell lines. Biochem Biophys Res Commun. 2008; 373(4):607-612.

143. Gao W, Shen H, Liu L, Xu J, Shu Y. MiR-21 overexpression in human primary squamous cell lung carcinoma is associated with poor patient prognosis. J Cancer Res Clin Oncol. 2010; 137(4):557-566.

144. Yang Y, Li X, Yang Q, Wang X, Zhou Y, Jiang T, Ma Q, Wang YJ. The role of microRNA in human lung squamous cell carcinoma. Cancer Genet Cytogenet. 2010; 200(2):127133.

145. Watanabe K1, Emoto N, Hamano E, Sunohara M, Kawakami M, Kage H, Kitano K, Nakajima J, Goto A, Fukayama M, Nagase T, Yatomi Y, Ohishi N, Takai D. Genome structure-based screening identified epigenetically silenced microRNA associated with invasiveness in nonsmall-cell lung cancer. Int J Cancer. 2012; 130(11):25802590.

146. Miko E, Margitai Z, Czimmerer Z, Varkonyi I, Dezso B, Lanyi A, Bacso Z, Scholtz B. miR-126 inhibits proliferation of small cell lung cancer cells by targeting SLC7A5. FEBS Lett. 2011; 585(8):1191-1196.

147. Donzelli S, Fontemaggi G, Fazi F, Di Agostino S, Padula F, Biagioni F, Muti P, Strano S, Blandino G. MicroRNA-128-2 targets the transcriptional repressor E2F5 enhancing mutant p53 gain of function. Cell Death Differ. 2012;19(6):10381048.

148. Weiss GJ, Bemis LT, Nakajima E, Sugita M, Birks DK, Robinson WA, Varella-Garcia M, Bunn PA Jr. Haney J, Helfrich BA, Kato H, Hirsch FR, Franklin WA. EGFR regulation by microRNA in lung cancer: correlation with clinical response and survival to gefitinib and EGFR expression in cell lines. Ann Oncol. 2008; 19(6):10531059.

149. Chen JF, Mandel EM, Thomson JM, Wu Q, Callis TE, Hammond SM, Conlon FL, Wang DZ. The role of microRNA-1 and microRNA-133 in skeletal muscle proliferation and differentiation. Nat Genet. 2006; 38(2):228-233.

150. Wang X, Ling C, Bai Y, Zhao J. MicroRNA-206 is associated with invasion and metastasis of lung cancer. Anat Rec (Hoboken). 2010; 294(1):88-92.

151. Moriya Y, Nohata N, Kinoshita T, Mutallip M, Okamoto T, Yoshida S, Suzuki M, Yoshino I, Seki N. Tumor suppressive 
microRNA-133a regulates novel molecular networks in lung squamous cell carcinoma. J Hum Genet. 2012; 57(1):38-45.

152. Ramalingam S, Belani C. Systemic chemotherapy for advanced non-small cell lung cancer: recent advances and future directions. Oncologist. 2008;13(1):5-13.

153. National Lung Screening Trial Research Team, Aberle DR, Adams AM, Berg CD, Black WC, Clapp JD, Fagerstrom RM, Gareen IF, Gatsonis C, Marcus PM, Sicks JD. Reduced lung-cancer mortality with low-dose computed tomographic screening. N Engl J Med. 2011; 365(5):395-409.

154. Mitchell PS, Parkin RK, Kroh EM, Fritz BR, Wyman SK, Pogosova-Agadjanyan EL, Peterson A, Noteboom J, O'Briant KC, Allen A, Lin DW, Urban N, Drescher CW, et al. Circulating microRNAs as stable blood-based markers for cancer detection. Proc Natl Acad Sci U S A. 2008; 105(30):10513-10518.

155. Xi Y, Nakajima G, Gavin E, Morris CG, Kudo K, Hayashi K, Ju J. Systematic analysis of microRNA expression of RNA extracted from fresh frozen and formalin-fixed paraffin-embedded samples. RNA. 2007 Oct;13(10):16681674.

156. Li J, Smyth P, Flavin R, Cahill S, Denning K, Aherne S, Guenther SM, O'Leary JJ, Sheils O. Comparison of miRNA expression patterns using total RNA extracted from matched samples of formalin-fixed paraffin-embedded (FFPE) cells and snap frozen cells. BMC Biotechnol. 2007; 7:36.

157. Shen J, Todd NW, Zhang H, Yu L, Lingxiao X, Mei Y, Guarnera M, Liao J, Chou A, Lu CL, Jiang Z, Fang H, Katz RL, Jiang F. Plasma microRNAs as potential biomarkers for non-small-cell lung cancer. Lab Invest. 2011; 91(4):579587.

158. Zheng D, Haddadin S, Wang Y, Gu LQ, Perry MC, Freter CE, Wang MX. Plasma microRNAs as novel biomarkers for early detection of lung cancer. Int J Clin Exp Pathol. 2011; 4(6):575-586.

159. Tan X, Qin W, Zhang L, Hang J, Li B, Zhang C, Wan J, Zhou F, Shao K, Sun Y, Wu J, Zhang X, Qiu B et al. A 5-microRNA signature for lung squamous cell carcinoma diagnosis and hsa-miR-31 for prognosis. Clin Cancer Res. 2011; 17(21):6802-6811.

160. Boeri M, Verri C, Conte D, Roz L, Modena P, Facchinetti F, Calabro E, Croce CM, Pastorino U, Sozzi G. MicroRNA signatures in tissues and plasma predict development and prognosis of computed tomography detected lung cancer. Proc Natl Acad Sci U S A. 2011; 108(9):3713-3718.

161. Barshack I, Lithwick-Yanai G, Afek A, Rosenblatt K, Tabibian-Keissar H, Zepeniuk M, Cohen L, Dan H, Zion O, Strenov Y, Polak-Charcon S, Perelman M. MicroRNA expression differentiates between primary lung tumors and metastases to the lung. Pathol Res Pract. 2010; 206(8):578584.

162. Xie Y, Todd NW, Liu Z, Zhan M, Fang H, Peng H, Alattar M, Deepak J, Stass SA, Jiang F. Altered miRNA expression in sputum for diagnosis of non-small cell lung cancer. Lung
Cancer. 2010; 67(2):170-176.

163. Yu L, Todd NW, Xing L, Xie Y, Zhang H, Liu Z, Fang H, Zhang J, Katz RL, Jiang F. Early detection of lung adenocarcinoma in sputum by a panel of microRNA markers. Int J Cancer. 2010; 127(12):2870-2878.

164. Xing L, Todd NW, Yu L, Fang H, Jiang F. Early detection of squamous cell lung cancer in sputum by a panel of microRNA markers. Mod Pathol. 2010; 23(8):1157-1164.

165. Roa WH, Kim JO, Razzak R, Du H, Guo L, Singh R, Gazala S, Ghosh S, Wong E, Joy AA, Xing JZ, Bedard EL. Sputum microRNA profiling: a novel approach for the early detection of non-small cell lung cancer. Clin Invest Med. 2012; 35(5):E271.

166. Lebanony D, Benjamin H, Gilad S, Ezagouri M, Dov A, Ashkenazi K, Gefen N, Izraeli S, Rechavi G, Pass H, Nonaka D, Li J, Spector Y, et al. Diagnostic assay based on hsa-miR-205 expression distinguishes squamous from nonsquamous non-small-cell lung carcinoma. J Clin Oncol. 2009; 27(12):2030-2037.

167. Bishop JA, Benjamin H, Cholakh H, Chajut A, Clark DP, Westra WH. Accurate classification of non-small cell lung carcinoma using a novel microRNA-based approach. Clin Cancer Res. 2010; 16(2):610-619.

168. Landi MT, Zhao Y, Rotunno M, Koshiol J, Liu H, Bergen AW, Rubagotti M, Goldstein AM, Linnoila I, Marincola FM, Tucker MA, Bertazzi PA, Pesatori AC, et al. MicroRNA expression differentiates histology and predicts survival of lung cancer. Clin Cancer Res. 2010; 16(2):430441.

169. Yu SL, Chen HY, Chang GC, Chen CY, Chen HW, Singh $\mathrm{S}$, Cheng CL, Yu CJ, Lee YC, Chen HS, Su TJ, Chiang $\mathrm{CC}, \mathrm{Li} \mathrm{HN}$, et al. MicroRNA signature predicts survival and relapse in lung cancer. Cancer Cell. 2008; 13(1):48-57.

170. Heegaard NH, Schetter AJ, Welsh JA, Yoneda M, Bowman ED, Harris CC. Circulating micro-RNA expression profiles in early stage nonsmall cell lung cancer. Int J Cancer. 2012; 130(6):1378-1386.

171. Meng W, Ye Z, Cui R, Perry J, Dedousi-Huebner V, Huebner A, Wang Y, Li B, Volinia S, Nakanishi H, Kim T, Suh SS, Ayers LW et al. MicroRNA-31 predicts the presence of lymph node metastases and survival in patients with lung adenocarcinoma. Clin Cancer Res. 2013; 19(19):54235433.

172. Raponi M, Dossey L, Jatkoe T, Wu X, Chen G, Fan H, Beer DG. MicroRNA classifiers for predicting prognosis of squamous cell lung cancer. Cancer Res. 2009; 69(14):57765783.

173. Wu C, Cao Y, He Z, He J, Hu C, Duan H, Jiang J. Serum levels of miR-19b and miR-146a as prognostic biomarkers for non-small cell lung cancer. Tohoku J Exp Med. 2014; 232(2):85-95.

174. Li J, Yang H, Li Y, Liu Y, Chen S, Qi C, Zhang Q, Lan T, He X, Guan XY, Wang L. microRNA-146 up-regulation predicts the prognosis of non-small cell lung cancer by 
miRNA in situ hybridization. Exp Mol Pathol. 2014; 96(2):195-199.

175. Donnem T, Eklo K, Berg T, Sorbye SW, Lonvik K, Al-Saad S, Al-Shibli K, Andersen S, Stenvold H, Bremnes RM, Busund LT. Prognostic impact of MiR-155 in non-small cell lung cancer evaluated by in situ hybridization. J Transl Med. 201; 9:6.

176. Xu TP, Zhu CH, Zhang J, Xia R, Wu FL, Han L, Shen H, Liu LX, Shu YQ. MicroRNA-155 expression has prognostic value in patients with non-small cell lung cancer and digestive system carcinomas. Asian Pac J Cancer Prev. 2013;14(12):7085-7090.

177. Donnem T, Lonvik K, Eklo K, Berg T, Sorbye SW, AlShibli K, Al-Saad S, Andersen S, Stenvold H, Bremnes RM, Busund LT. Independent and tissue-specific prognostic impact of miR-126 in nonsmall cell lung cancer: coexpression with vascular endothelial growth factor-A predicts poor survival. Cancer. 2011; 117(14):3193-3200.

178. Markou A, Tsaroucha EG, Kaklamanis L, Fotinou M, Georgoulias V, Lianidou ES. Prognostic value of mature microRNA-21 and microRNA-205 overexpression in nonsmall cell lung cancer by quantitative real-time RT-PCR. Clin Chem. 2008; 54(10):1696-1704.

179. Gao W, Yu Y, Cao H, Shen H, Li X, Pan S, Shu Y. Deregulated expression of miR-21, miR-143 and miR-181a in non small cell lung cancer is related to clinicopathologic characteristics or patient prognosis. Biomed Pharmacother. 2010; 64(6):399-408.

180. Liu XG, Zhu WY, Huang YY, Ma LN, Zhou SQ, Wang YK, Zeng F, Zhou JH, Zhang YK. High expression of serum miR-21 and tumor miR-200c associated with poor prognosis in patients with lung cancer. Med Oncol. 2012; 29(2):618-626.

181. Saito M, Schetter AJ, Mollerup S, Kohno T, Skaug V, Bowman ED, Mathe EA, Takenoshita S, Yokota J, Haugen A, Harris CC. The association of microRNA expression with prognosis and progression in early-stage, non-small cell lung adenocarcinoma: a retrospective analysis of three cohorts. Clin Cancer Res. 2011; 17(7):1875-1782.

182. Voortman J, Goto A, Mendiboure J, Sohn JJ, Schetter AJ, Saito M, Dunant A, Pham TC, Petrini I, Lee A, Khan MA, Hainaut P, Pignon JP, Brambilla E, Popper HH, Filipits M, Harris CC, Giaccone G. MicroRNA expression and clinical outcomes in patients treated with adjuvant chemotherapy after complete resection of non-small cell lung carcinoma. Cancer Res. 2010; 70(21):8288-8298.

183. Wang ZX, Bian HB, Wang JR, Cheng ZX, Wang KM, De W. Prognostic significance of serum miRNA-21 expression in human non-small cell lung cancer. J Surg Oncol. 2011; 104(7):847-851.

184. Zhao C, Xu Y, Zhang Y, Tan W, Xue J, Yang Z, Zhang Y, $\mathrm{Lu} \mathrm{Y}, \mathrm{Hu} \mathrm{X}$. Downregulation of miR-145 contributes to lung adenocarcinoma cell growth to form brain metastases. Oncol Rep. 2013; 30(5):2027-2034.

185. Wang Z, Chen Z, Gao Y, Li N, Li B, Tan F, Tan X, Lu
N, Sun Y, Sun J, Sun N, He J. DNA hypermethylation of microRNA-34b/c has prognostic value for stage non-small cell lung cancer. Cancer Biol Ther. 2011; 11(5):490-496.

186. Gallardo E, Navarro A, Viñolas N, Marrades RM, Diaz T, Gel B, Quera A, Bandres E, Garcia-Foncillas J, Ramirez J, Monzo M. miR-34a as a prognostic marker of relapse in surgically resected non-small-cell lung cancer. Carcinogenesis. 2009; 30(11):1903-1909.

187. Tanaka N, Toyooka S, Soh J, Kubo T, Yamamoto H, Maki Y, Muraoka T, Shien K, Furukawa M, Ueno T, Asano H, Tsukuda K, Aoe K, Miyoshi S. Frequent methylation and oncogenic role of microRNA-34b/c in small-cell lung cancer. Lung Cancer. 2012; 76(1):32-38.

188. Kitano K, Watanabe K, Emoto N, Kage H, Hamano E, Nagase T, Sano A, Murakawa T, Nakajima J, Goto A, Fukayama M, Yatomi Y, Ohishi N, Takai D. CpG island methylation of microRNAs is associated with tumor size and recurrence of non-small-cell lung cancer. Cancer Sci. 2011; 102(12):2126-2131.

189. Brueckner B, Stresemann C, Kuner R, Mund C, Musch T, Meister M, Sültmann H, Lyko F. The human let-7a-3 locus contains an epigenetically regulated microRNA gene with oncogenic function. Cancer Res. 2007; 67(4):1419-1423.

190. Nasser MW, Datta J, Nuovo G, Kutay H, Motiwala T, Majumder S, Wang B, Suster S, Jacob ST, Ghoshal K. Down-regulation of micro-RNA-1 (miR-1) in lung cancer. Suppression of tumorigenic property of lung cancer cells and their sensitization to doxorubicin-induced apoptosis by miR-1. J Biol Chem. 2008; 283(48):33394-33405.

191. Fabbri M, Garzon R, Cimmino A, Liu Z, Zanesi N, Callegari E, Liu S, Alder H, Costinean S, FernandezCymering C, Volinia S, Guler G, Morrison CD, et al. MicroRNA-29 family reverts aberrant methylation in lung cancer by targeting DNA methyltransferases 3A and 3B. Proc Natl Acad Sci U S A. 2007; 104(40):15805-15810.

192. Megiorni F, Pizzuti A, Frati L. Clinical Significance of MicroRNA Expression Profiles and Polymorphisms in Lung Cancer Development and Management. Patholog Res Int. 2011; 2011:780652.

193. Nicoloso MS, Sun H, Spizzo R, Kim H, Wickramasinghe P, Shimizu M, Wojcik SE, Ferdin J, Kunej T, Xiao L, Manoukian S, Secreto G, Ravagnani F, et al. Singlenucleotide polymorphisms inside microRNA target sites influence tumor susceptibility. Cancer Res. 2010; 70(7):2789-2798.

194. Tian T, Shu Y, Chen J, Hu Z, Xu L, Jin G, Liang J, Liu P, Zhou X, Miao R, Ma H, Chen Y, Shen H. A functional genetic variant in microRNA-196a2 is associated with increased susceptibility of lung cancer in Chinese. Cancer Epidemiol Biomarkers Prev. 2009; 18(4):1183-1187.

195. Liu XH, Lu KH, Wang KM, Sun M, Zhang EB, Yang JS, Yin DD, Liu ZL, Zhou J, Liu ZJ, De W, Wang ZX. MicroRNA-196a promotes non-small cell lung cancer cell proliferation and invasion through targeting HOXA5. BMC Cancer. 2012; 12:348. 
196. Xiong F, Wu C, Chang J, Yu D, Xu B, Yuan P, Zhai K, $\mathrm{Xu}$ J, Tan W, Lin D. Genetic variation in an miRNA-1827 binding site in MYCL1 alters susceptibility to small-cell lung cancer. Cancer Res. 2011; 71(15):5175-5181.

197. Kim JS, Choi YY, Jin G, Kang HG, Choi JE, Jeon HS, Lee WK, Kim DS, Kim CH, Kim YJ, Son JW, Jung TH, Park JY. Association of a common AGO1 variant with lung cancer risk: a twostage case-control study. Mol Carcinog. 2010; 49(10):913-921.

198. Rotunno M, Zhao Y, Bergen AW, Koshiol J, Burdette L, Rubagotti M, Linnoila RI, Marincola FM, Bertazzi PA, Pesatori AC, Caporaso NE, McShane LM, Wang E, Landi MT. Inherited polymorphisms in the RNA-mediated interference machinery affect microRNA expression and lung cancer survival. Br J Cancer. 2010; 103(12):1870 1874.

199. Campayo M, Navarro A, Viñolas N, Tejero R, Muñoz C, Diaz T, Marrades R, Cabanas ML, Gimferrer JM, Gascon P, Ramirez J, Monzo M. A dual role for KRT81: a miR-SNP associated with recurrence in non-small-cell lung cancer and a novel marker of squamous cell lung carcinoma. PLoS One. 2011;6(7):e22509.

200. Ding C, Li C, Wang H, Li B, Guo Z. A miR-SNP of the $\mathrm{XPO} 5$ gene is associated with advanced non-small-cell lung cancer. Onco Targets Ther. 2013; 6:877-881.

201. Zhong M, Ma X, Sun C, Chen L. MicroRNAs reduce tumor growth and contribute to enhance cytotoxicity induced by gefitinib in non-small cell lung cancer. Chem Biol Interact. 2010; 184(3):431-438.

202. Cho WC, Chow AS, Au JS. Restoration of tumour suppressor hsa-miR-145 inhibits cancer cell growth in lung adenocarcinoma patients with epidermal growth factor receptor mutation. Eur J Cancer. 2009; 45(12):2197-2206.

203. Qiu T, Zhou L, Wang T, Xu J, Wang J, Chen W, Zhou X, Huang Z, Zhu W, Shu Y, Liu P. miR-503 regulates the resistance of non-small cell lung cancer cells to cisplatin by targeting Bcl-2. Int J Mol Med. 2013; 32(3):593-598.

204. Li B, Ren S, Li X, Wang Y, Garfield D, Zhou S, Chen X, Su C, Chen M, Kuang P, Gao G, He Y, Fan L, et al. MiR21 overexpression is associated with acquired resistance of EGFR-TKI in non-small cell lung cancer. Lung Cancer. 2014; 83(2):146-153.

205. Webster RJ, Giles KM, Price KJ, Zhang PM, Mattick JS, Leedman PJ. Regulation of epidermal growth factor receptor signaling in human cancer cells by microRNA-7. J Biol Chem. 2009; 284(9):5731-5741.

206. Rai K, Takigawa N, Ito S, Kashihara H, Ichihara E, Yasuda T, Shimizu K, Tanimoto M, Kiura K. Liposomal delivery of MicroRNA-7-expressing plasmid overcomes epidermal growth factor receptor tyrosine kinase inhibitor-resistance in lung cancer cells. Mol Cancer Ther. 2011; 10(9):17201727.

207. Schaefer U, Voloshanenko O, Willen D, Walczak H. TRAIL: a multifunctional cytokine. Front Biosci. 2007; 12:3813-3824.
208. Enfield KS, Stewart GL, Pikor LA, Alvarez CE, Lam S, Lam WL, Chari R. MicroRNA gene dosage alterations and drug response in lung cancer. J Biomed Biotechnol. 2011; 2011:474632.

209. Zou HY, Li Q, Lee JH, Arango ME, McDonnell SR, Yamazaki S, Koudriakova TB, Alton G, Cui JJ, Kung PP, Nambu MD, Los G, Bender SL, et al. An orally available small-molecule inhibitor of c-Met, PF-2341066, exhibits cytoreductive antitumor efficacy through antiproliferative and antiangiogenic mechanisms. Cancer Res. 2007; 67(9):4408-4417.

210. Galluzzi L, Morselli E, Vitale I, Kepp O, Senovilla L, Criollo A, Servant N, Paccard C, Hupé P, Robert T, Ripoche H, Lazar V, Harel-Bellan A. miR-181a and miR-630 regulate cisplatin-induced cancer cell death. Cancer Res. 2010; 70(5):1793-1803.

211. Foss KM, Sima C, Ugolini D, Neri M, Allen KE, Weiss GJ. miR-1254 and miR-574-5p: serumbased microRNA biomarkers for early-stage non-small cell lung cancer. J Thorac Oncol. 2011; 6(3):482-488.

212. Bianchi F, Nicassio F, Marzi M, Belloni E, Dall'olio V, Bernard L, Pelosi G, Maisonneuve P, Veronesi G, Di Fiore PP. A serum circulating miRNA diagnostic test to identify asymptomatic high-risk individuals with early stage lung cancer. EMBO Mol Med. 2011; 3(8):495-503.

213. Gao W, Lu X, Liu L, Xu J, Feng D, Shu Y. MiRNA-21: a biomarker predictive for platinum-based adjuvant chemotherapy response in patients with non-small cell lung cancer Cancer Biol Ther. 2012; 13(5):330-340.

214. Qiu T, Zhou L, Wang T, Xu J, Wang J, Chen W, Zhou X, Huang Z, Zhu W, Shu Y, Liu P. miR-503 regulates the resistance of non-small cell lung cancer cells to cisplatin by targeting Bcl-2. Int J Mol Med. 2013; 32(3):593-598.

215. Zhou L, Qiu T, Xu J, Wang T, Wang J, Zhou X, Huang Z, Zhu W, Shu Y, Liu P. miR-135a/b modulate cisplatin resistance of human lung cancer cell line by targeting MCL1 Pathol Oncol Res. 2013; 19(4):677-683.

216. Zhang JG, Guo JF, Liu DL, Liu Q, Wang JJ. MicroRNA-101 exerts tumor-suppressive functions in non-small cell lung cancer through directly targeting enhancer of zeste homolog 2. J Thorac Oncol. 2011; 6(4):671-678.

217. Yin J, Wang M, Jin C, Qi Q. miR-101 sensitizes A549 NSCLC cell line to CDDP by activating caspase 3-dependent apoptosis. Oncol Lett. 2014; 7(2):461-465.

218. Rothschild SI. Epigenetic Therapy in Lung Cancer - Role of microRNAs. Front Oncol. 2013; 3:158.

219. Wang XC, Wang W, Zhang ZB, Zhao J, Tan XG, Luo JC. Overexpression of miRNA-21 promotes radiationresistance of non-small cell lung cancer. Radiat Oncol. 2013; 8:146.

220. Trang P, Medina PP, Wiggins JF, Ruffino L, Kelnar K, Omotola M, Homer R, Brown D, Bader AG, Weidhaas JB, Slack FJ. Regression of murine lung tumors by the let-7 microRNA. Oncogene. 2010; 29(11):1580-1587. 
221. Esquela-Kerscher A, Trang P, Wiggins JF, Patrawala L, Cheng A, Ford L, Weidhaas JB, Brown D, Bader AG, Slack FJ. The let-7 microRNA reduces tumor growth in mouse models of lung cancer. Cell Cycle. 2008; 7(6):759-764.

222. Wang QZ, Lv YH, Gong YH, Li ZF, Xu W, Diao Y, Xu R. Double-stranded Let-7 mimics, potential candidates for cancer gene therapy. J Physiol Biochem. 2012; 68(1):107119.

223. Wiggins JF, Ruffino L, Kelnar K, Omotola M, Patrawala L, Brown D, Bader AG. Development of a lung cancer therapeutic based on the tumor suppressor microRNA-34. Cancer Res. 2010; 70(14):5923-5930.

224. Trang P, Wiggins JF, Daige CL, Cho C, Omotola M, Brown D, Weidhaas JB, Bader AG, Slack FJ. Systemic delivery of tumor suppressor microRNA mimics using a neutral lipid emulsion inhibits lung tumors in mice. Mol Ther. 2011; 19(6):1116-1122.

225. Rai K, Takigawa N, Ito S, Kashihara H, Ichihara E, Yasuda T, Shimizu K, Tanimoto M, Kiura K. Liposomal delivery of MicroRNA-7-expressing plasmid overcomes epidermal growth factor receptor tyrosine kinase inhibitor-resistance in lung cancer cells. Mol Cancer Ther. 2011; 10(9):1720 1727.

226. Zhao J, Kelnar K, Bader AG. In-depth analysis shows synergy between erlotinib and miR-34a. PLoS One. 2014; 9(2):e89105.

227. Mudduluru G, Ceppi P, Kumarswamy R, Scagliotti GV, Papotti M, Allgayer H. Regulation of Axl receptor tyrosine kinase expression by miR-34a and miR-199a/b in solid cancer. Oncogene. 2011; 30(25):2888-2899.

228. Kaller M, Liffers ST, Oeljeklaus S, Kuhlmann K, Röh S, Hoffmann R, Warscheid B, Hermeking H. Genome-wide characterization of miR-34a induced changes in protein and mRNA expression by a combined pulsed SILAC and microarray analysis. Mol Cell Proteomics. 2011; 10(8):M111.010462.

229. Mirna Therapeutics. Press Release: Mirna Therapeutics is First to Advance MicroRNA into the Clinic for Cancer. Corporate website. 2013;

230. Krutzfeldt J, Rajewsky N, Braich R, Rajeev KG, Tuschl T, Manoharan M, Stoffel M. Silencing of microRNAs in vivo with 'antagomirs'. Nature. 2005; 438(7068):685-689.

231. Elmen J, Lindow M, Schutz S, Lawrence M, Petri A, Obad S, Lindholm M, Hedtjarn M, Hansen HF, Berger U, Gullans S, Kearney P, Sarnow P, et al. LNA-mediated microRNA silencing in non-human primates. Nature. 2008; 452(7189):896-899.

232. Li YJ, Zhang YX, Wang PY, Chi YL, Zhang C, Ma Y, Lv CJ, Xie SY. Regression of A549 lung cancer tumors by antimiR-150 vector. Oncol Rep. 2012; 27(1):129-134.

233. Ebert MS, Neilson JR, Sharp PA. MicroRNA sponges: competitive inhibitors of small RNAs in mammalian cells. Nat Methods. 2007; 4(9):721-726.

234. Ebert MS, Sharp PA. MicroRNA sponges: progress and possibilities. RNA. 2010; 16(11):2043-2050.

235. Obad S, dos Santos CO, Petri A, Heidenblad M, Broom O, Ruse C, Fu C, Lindow M, Stenvang J, Straarup EM, Hansen HF, Koch T, Pappin D, et al. Silencing of microRNA families by seed-targeting tiny LNAs. Nat Genet. 2011; 43(4):371-378.

236. Matsubara H, Sakakibara K, Kunimitsu T, Matsuoka H, Kato K, Oyachi N, Dobashi Y, Matsumoto M. Non-small cell lung carcinoma therapy using mTOR-siRNA. Int J Clin Exp Pathol. 2012; 5(2):119-125.

237. Xu C, Gui Q, Chen W, Wu L, Sun W, Zhang N, Xu Q, Wang J, Fu X. Small interference RNA targeting tissue factor inhibits human lung adenocarcinoma growth in vitro and in vivo. J Exp Clin Cancer Res. 2011; 30:63.

238. Wu LN, Xue YJ, Zhang LJ, Ma XM, Chen JF. Si-RNA mediated knockdown of CELF1 gene suppressed the proliferation of human lung cancer cells. Cancer Cell Int. 2013; 13(1):115.

239. Liu Y, Yan X, Liu N, Zhou J, Liu J, Pang H, Cao J, Liu Y, Wang Y, Liu L, Zhang H. Lentivirus-delivered ZEB-1 small interfering RNA inhibits lung adenocarcinoma cell growth in vitro and in vivo. J Cancer Res Clin Oncol. 2012;138(8):1329-1338.

240. Guo X, Wang W, Hu J, Feng K, Pan Y, Zhang L, Feng Y. Lentivirus-mediated RNAi knockdown of NUPR1 inhibits human nonsmall cell lung cancer growth in vitro and in vivo. Anat Rec (Hoboken). 2012; 295(12):2114-2121.

241. Liu L, Zhang N, Liu J, Min J, Ma N, Liu N, Liu Y, Zhang $\mathrm{H}$. Lentivirus-mediated siRNA interference targeting SGO1 inhibits human NSCLC cell growth. Tumour Biol. 2012; 33(2):515-521.

242. Yang Y, Bai Y, Xie G, Zhang N, Ma YP, Chen LJ, Jiang Y, Zhao X, Wei YQ, Deng HX. Efficient inhibition of nonsmall-cell lung cancer xenograft by systemic delivery of plasmid-encoding short-hairpin RNA targeting VEGF. Cancer Biother Radiopharm. 2010; 25(1):65-73.

243. Feng Y, Hu J, Ma J, Feng K, Zhang X, Yang S, Wang W, Zhang J, Zhang Y. RNAi-mediated silencing of VEGF-C inhibits non-small cell lung cancer progression by simultaneously down-regulating the CXCR4, CCR7, VEGFR-2 and VEGFR-3-dependent axes-induced ERK, p38 and AKT signalling pathways. Eur J Cancer. 2011; 47(15):2353-2363.

244. Chen YS, Li HR, Miao Y, Chen WY, Li YT, Wang GQ, $\mathrm{Wu} \mathrm{ZC}$. Local injection of lentivirus-delivered livinshRNA suppresses lung adenocarcinoma growth by inducing a G0/ G1 phase cell cycle arrest. Int J Clin Exp Pathol. 2012; 5(8):796-805.

245. Li C, Zhang X, Cheng L, Dai L, Xu F, Zhang J, Tian H, Chen X, Shi G, Li Y, Du T, Zhang S, Wei Y, Deng H. RNA interference targeting human FAK and EGFR suppresses human non-small-cell lung cancer xenograft growth in nude mice. Cancer Gene Ther. 2013; 20(2):101-108.

246. Zhang M, Zhang X, Bai CX, Song XR, Chen J, Gao L, Hu 
J, Hong QY, West MJ, Wei MQ. Silencing the epidermal growth factor receptor gene with RNAi may be developed as a potential therapy for non small cell lung cancer. Genet Vaccines Ther. 2005; 3:5.

247. Takahashi M, Chiyo T, Okada T, Hohjoh H. Specific inhibition of tumor cells by oncogenic EGFR specific silencing by RNA interference. PLoS One. 2013; 8(8):e73214.

248. Chen G, Kronenberger P, Teugels E, Umelo IA, De Grève J. Effect of siRNAs targeting the EGFR T790M mutation in a non-small cell lung cancer cell line resistant to EGFR tyrosine kinase inhibitors and combination with various agents. Biochem Biophys Res Commun. 2013; 431(3):623629.

249. Chen G, Kronenberger P, Teugels E, Umelo IA, De Grève J. Targeting the epidermal growth factor receptor in nonsmall cell lung cancer cells: the effect of combining RNA interference with tyrosine kinase inhibitors or cetuximab. BMC Med. 2012;10:28.

250. Zhang Z, Jiang G, Yang F, Wang J. Knockdown of mutant K-ras expression by adenovirus-mediated siRNA inhibits the in vitro and in vivo growth of lung cancer cells. Cancer Biol Ther. 2006; 5(11):1481-1486.

251. Sunaga N, Shames DS, Girard L, Peyton M, Larsen JE, Imai H, Soh J, Sato M, Yanagitani N, Kaira K, Xie Y, Gazdar AF, Mori M, et al. Knockdown of oncogenic KRAS in non-small cell lung cancers suppresses tumor growth and sensitizes tumor cells to targeted therapy. Mol Cancer Ther. 2011; 10(2):336-346.

252. Barbie DA, Tamayo P, Boehm JS, Kim SY, Moody SE, Dunn IF, et al. Systematic RNA interference reveals that oncogenic KRAS-driven cancers require TBK1. Nature. 2009; 462(7269):108-112.

253. Singh A, Greninger P, Rhodes D, Koopman L, Violette S, Bardeesy N, et al. A gene expression signature associated with "K-ras addiction" reveals regulators of EMT and tumor cell survival. Cancer Cell. 2009; 15(6):489-500.

254. Luo J, Emanuele MJ, Li D, Creighton CJ, Schlabach MR, Westbrook TF, et al. A genome-wide RNAi screen identifies multiple synthetic lethal interactions with the ras oncogene. Cell. 2009; 137(5):835-848.

255. Xia H, Zhang W, Li Y, Guo N, Yu C. EZH2 Silencing with RNA Interference Induces G2/M Arrest in Human Lung Cancer Cells In Vitro. Biomed Res Int. 2014;2014:348728.

256. Xia H, Yu CH, Zhang Y, Yu J, Li J, Zhang W, Zhang B, Li Y, Guo N. EZH2 silencing with RNAi enhances irradiationinduced inhibition of human lung cancer growth in vitro and in vivo. Oncol Lett. 2012; 4(1):135-140.

257. Guo W, Chen W, Yu W, Huang W, Deng W. Small interfering RNA-based molecular therapy of cancers. Chin J Cancer. 2013; 32(9):488-493.

258. Burnett JC, Rossi JJ, Tiemann K. Current progress of siRNA/shRNA therapeutics in clinical trials. Biotechnol J. 2011; 6(9):1130-1146.
259. Davidson BL, McCray PB Jr. Current prospects for RNA interference-based therapies. Nat Rev Genet. 2011;12(5):329-340.

260. Davis ME, Zuckerman JE, Choi CH, Seligson D, Tolcher A, Alabi CA, Yen Y, Heidel JD, Ribas A. Evidence of RNAi in humans from systemically administered siRNA via targeted nanoparticles. Nature. 2010; 464(7291):1067-1670.

261. Decatur WA, Fournier MJ. rRNA modifications and ribosome function. Trends Biochem Sci. 2002; 27(7):344351.

262. Ganot P, Caizergues-Ferrer M, Kiss T. The family of box ACA small nucleolar RNAs is defined by an evolutionarily conserved secondary structure and ubiquitous sequence elements essential for RNA accumulation. Genes Dev. 1997; 11(7):941-956.

263. Calore F, Lovat F, Garofalo M. Non-coding RNAs and cancer. Int J Mol Sci. 2013; 14(8):17085-17110.

264. Bortolin ML, Kiss T. Human U19 intron-encoded snoRNA is processed from a long primary transcript that possesses little potential for protein coding. RNA. 1998; 4(4):445454.

265. Smith CM, Steitz JA. Classification of gas5 as a multismall-nucleolar-RNA (snoRNA) host gene and a member of the 5'-terminal oligopyrimidine gene family reveals common features of snoRNA host genes. Mol Cell Biol. 1998; 18(12):6897-6909.

266. Coughlin DJ, Pleiss JA, Walker SC, Whitworth GB, Engelke DR. Genome-wide search for yeast RNase P substrates reveals role in maturation of intron-encoded box C/D small nucleolar RNAs. Proc Natl Acad Sci U S A. 2008; 105(34):12218-12223.

267. Brameier M, Herwig A, Reinhardt R, Walter L, Gruber J. Human box C/D snoRNAs with miRNA like functions: expanding the range of regulatory RNAs. Nucleic Acids Res. 2011; 39(2):675-686.

268. Liao J, Yu L, Mei Y, Guarnera M, Shen J, Li R, Liu Z, Jiang F. Small nucleolar RNA signatures as biomarkers for nonsmall-cell lung cancer. Mol Cancer. 2010; 9:198.

269. Gebhart E. Double minutes, cytogenetic equivalents of gene amplification, in human neoplasia - a review. Clin Transl Oncol. 2005; 7(11):477-485.

270. Schwab M. Oncogene amplification in solid tumors. Semin Cancer Biol. 1999; 9(4):319-325.

271. Li R, Wang H, Bekele BN, Yin Z, Caraway NP, Katz RL, Stass SA, Jiang F. Identification of putative oncogenes in lung adenocarcinoma by a comprehensive functional genomic approach. Oncogene. 2006; 25(18):2628-2635.

272. Jiang F, Yin Z, Caraway NP, Li R, Katz RL. Genomic profiles in stage I primary non small cell lung cancer using comparative genomic hybridization analysis of cDNA microarrays. Neoplasia. 2004; 6(5):623-635.

273. Mei YP, Liao JP, Shen J, Yu L, Liu BL, Liu L, Li RY, Ji L, Dorsey SG, Jiang ZR, Katz RL, Wang JY, Jiang F. Small nucleolar RNA 42 acts as an oncogene in lung 
tumorigenesis. Oncogene. 2012; 31(22):2794-2804.

274. Siomi MC, Sato K, Pezic D, Aravin AA. PIWI-interacting small RNAs: the vanguard of genome defence. Nat Rev Mol Cell Biol. 2011; 12(4):246-258.

275. Carmell MA, Xuan Z, Zhang MQ, Hannon GJ. The Argonaute family: tentacles that reach into RNAi, developmental control, stem cell maintenance, and tumorigenesis. Genes Dev. 2002; 16(21):2733-2742.

276. Brennecke J, Aravin AA, Stark A, Dus M, Kellis M, Sachidanandam R, Hannon GJ. Discrete small RNAgenerating loci as master regulators of transposon activity in Drosophila. Cell. 2007; 128(6):1089-1103.

277. Saito K, Sakaguchi Y, Suzuki T, Suzuki T, Siomi H, Siomi MC. Pimet, the Drosophila homolog of HEN1, mediates 2'-O-methylation of Piwi- interacting RNAs at their 3' ends. Genes Dev. 2007; 21(13):1603-1608.

278. Kirino Y, Mourelatos Z. Mouse Piwi-interacting RNAs are 2'-O-methylated at their 3' termini. Nat Struct Mol Biol. 2007; 14(4):347-348.

279. Kim VN, Han J, Siomi MC. Biogenesis of small RNAs in animals. Nat Rev Mol Cell Biol. 2009; 10(2):126-139.

280. Ross RJ, Weiner MM, Lin H. PIWI proteins and PIWI-interacting RNAs in the soma. Nature. 2014; 505(7483):353-359.

281. Thomson T, Lin H. The biogenesis and function of PIWI proteins and piRNAs: progress and prospect. Annu Rev Cell Dev Biol. 2009; 25:355-376.

282. Cheng J, Guo JM, Xiao BX, Miao Y, Jiang Z, Zhou H, Li QN. piRNA, the new non-coding RNA, is aberrantly expressed in human cancer cells. Clin Chim Acta. 2011; 412(17-18):1621-1625.

283. Qiao D, Zeeman AM, Deng W, Looijenga LH, Lin H. Molecular characterization of hiwi, a human member of the piwi gene family whose overexpression is correlated to seminomas. Oncogene. 2002; 21(25):3988-3999.

284. Suzuki R, Honda S, Kirino Y. PIWI Expression and Function in Cancer. Front Genet. 2012; 3:204.

285. Liang D, Fang Z, Dong M, Liang C, Xing C, Zhao J, Yang $\mathrm{Y}$. Effect of RNA interference-related HiWi gene expression on the proliferation and apoptosis of lung cancer stem cells. Oncol Lett. 2012; 4(1):146-150.

286. Liang D, Dong M, Hu LJ, Fang ZH, Xu X, Shi EH, Yang YJ. Hiwi knockdown inhibits the growth of lung cancer in nude mice. Asian Pac J Cancer Prev. 2013;14(2):10671072.

287. Kapranov P, Cheng J, Dike S, Nix DA, Duttagupta R, Willingham AT, Stadler PF, Hertel J, Hackermüller J, Hofacker IL, Bell I, Cheung E, Drenkow J, et al. RNA maps reveal new RNA classes and a possible function for pervasive transcription. Science. 2007; 316(5830):14841488.

288. Gomes AQ, Nolasco S, Soares H. Non-coding RNAs: multi-tasking molecules in the cell. Int J Mol Sci. 2013; 14(8):16010-16039.
289. Ponting CP, Oliver PL, Reik W. Evolution and functions of long noncoding RNAs. Cell. 2009; 136(4):629-641.

290. Derrien T, Johnson R, Bussotti G, Tanzer A, Djebali S, Tilgner H, Guernec G, Martin D, Merkel A, Knowles DG, et al. The GENCODE v7 catalog of human long noncoding RNAs: analysis of their gene structure, evolution, and expression. Genome Res. 2012; 22(9):1775-1789.

291. Wang KC, Chang HY. Molecular mechanisms of long noncoding RNAs. Mol Cell. 2011; 43(6):904-914.

292. Mattick JS, Amaral PP, Dinger ME, Mercer TR, Mehler MF. RNA regulation of epigenetic processes. Bioessays. 2009; 31(1):51-59.

293. Yochum GS, Cleland R, McWeeney S, Goodman RH. An antisense transcript induced by Wnt/beta-catenin signaling decreases E2F4. J Biol Chem. 2007; 282(2):871-878.

294. Prensner JR, Iyer MK, Balbin OA, Dhanasekaran SM, Cao Q, Brenner JC, Laxman B, Asangani IA, Grasso CS, Kominsky HD, Cao X, Jing X, Wang X, et al. Transcriptome sequencing across a prostate cancer cohort identifies PCAT-1, an unannotated lincRNA implicated in disease progression. Nat Biotechnol. 2011; 29(8):742-679.

295. Gupta RA, Shah N, Wang KC, Kim J, Horlings HM, Wong DJ, Tsai MC, Hung T, Argani P, Rinn JL, Wang Y, Brzoska P, Kong B, et al. Long non-coding RNA HOTAIR reprograms chromatin state to promote cancer metastasis. Nature. 2010; 464(7291):1071-1076.

296. Gibb EA, Brown CJ, Lam WL. The functional role of long non-coding RNA in human carcinomas. Mol Cancer. 2011; 10:38.

297. Barsyte-Lovejoy D, Lau SK, Boutros PC, Khosravi F, Jurisica I, Andrulis IL, Tsao MS, Penn LZ. The c-Myc oncogene directly induces the H19 noncoding RNA by allele-specific binding to potentiate tumorigenesis. Cancer Res. 2006; 66(10):5330-5337.

298. Ji P, Diederichs S, Wang W, Böing S, Metzger R, Schneider PM, Tidow N, Brandt B, Buerger H, Bulk E, Thomas M, Berdel WE, Serve H, et al. MALAT-1, a novel noncoding RNA, and thymosin beta4 predict metastasis and survival in early-stage non-small cell lung cancer. Oncogene. 2003; 22(39):8031-8041.

299. Yang L, Lin C, Liu W, Zhang J, Ohgi KA, Grinstein JD, Dorrestein PC, Rosenfeld MG. ncRNA- and Pc2 methylation-dependent gene relocation between nuclear structures mediates gene activation programs. Cell. 2011; 147(4):773-788.

300. Schmidt LH, Spieker T, Koschmieder S, Schäffers S, Humberg J, Jungen D, Bulk E, Hascher A, Wittmer D, Marra A, Hillejan L, Wiebe K, Berdel WE, et al. The long noncoding MALAT-1 RNA indicates a poor prognosis in non-small cell lung cancer and induces migration and tumor growth. J Thorac Oncol. 2011; 6(12):1984-1992.

301. Tano K, Mizuno R, Okada T, Rakwal R, Shibato J, Masuo Y, Ijiri K, Akimitsu N. MALAT-1 enhances cell motility of lung adenocarcinoma cells by influencing the expression 
of motility-related genes. FEBS Lett. 2010; 584(22):45754580 .

302. Gutschner T, Hämmerle M, Eissmann M, Hsu J, Kim Y, Hung G, Revenko A, Arun G, Stentrup M, Gross M, Zörnig M, MacLeod AR, Spector DL, et al. The noncoding RNA MALAT1 is a critical regulator of the metastasis phenotype of lung cancer cells. Cancer Res. 2013; 73(3):1180-1189.

303. Panzitt K, Tschernatsch MM, Guelly C, Moustafa T, Stradner M, Strohmaier HM, Buck CR, Denk H, Schroeder R, Trauner M, Zatloukal K. Characterization of HULC, a novel gene with striking up-regulation in hepatocellular carcinoma, as noncoding RNA. Gastroenterology. 2007; 132(1):330-342.

304. Fradet Y, Saad F, Aprikian A, Dessureault J, Elhilali M, Trudel C, Mâsse B, Piché L, Chypre C. uPM3, a new molecular urine test for the detection of prostate cancer. Urology. 2004; 64(2):311-315.

305. Weber DG, Johnen G, Casjens S, Bryk O, Pesch B, Jöckel KH, Kollmeier J, Brüning T. Evaluation of long noncoding RNA MALAT1 as a candidate blood-based biomarker for the diagnosis of non-small cell lung cancer. BMC Res Notes. 2013; 6:518.

306. Rinn JL, Kertesz M, Wang JK, Squazzo SL, Xu X, Brugmann SA, Goodnough LH, Helms JA, Farnham PJ, Segal E, Chang HY. Functional demarcation of active and silent chromatin domains in human HOX loci by noncoding RNAs. Cell. 2007; 129(7):1311-1323.

307. Zhang H, Chen Z, Wang X, Huang Z, He Z, Chen Y. Long non-coding RNA: a new player in cancer. J Hematol Oncol. 2013; 6:37.

308. Tang L, Zhang W, Su B, Yu B. Long noncoding RNA HOTAIR is associated with motility, invasion, and metastatic potential of metastatic melanoma. Biomed Res Int. 2013; 2013:251098.

309. Liu XH, Liu ZL, Sun M, Liu J, Wang ZX, De W. The long non-coding RNA HOTAIR indicates a poor prognosis and promotes metastasis in non-small cell lung cancer. BMC Cancer. 2013; 13:464.

310. Nakagawa T, Endo H, Yokoyama M, Abe J, Tamai K, Tanaka N, Sato I, Takahashi S, Kondo T, Satoh K. Large noncoding RNA HOTAIR enhances aggressive biological behavior and is associated with short disease-free survival in human non-small cell lung cancer. Biochem Biophys Res Commun. 2013; 436(2):319-324

311. Qiu M, Xu Y, Yang X, Wang J, Hu J, Xu L, Yin R. CCAT2 is a lung adenocarcinoma-specific long non-coding RNA and promotes invasion of non-small cell lung cancer. Tumour Biol. 2014.

312. Flockhart RJ, Webster DE, Qu K, Mascarenhas N, Kovalski J, Kretz M, Khavari PA. BRAFV600E remodels the melanocyte transcriptome and induces BANCR to regulate melanoma cell migration. Genome Res. 2012; 22(6):10061014.

313. Sun M, Liu XH, Wang KM, Nie FQ, Kong R, Yang JS, Xia R, Xu TP, Jin FY, Liu ZJ, Chen JF, Zhang EB, De W, et al. Downregulation of BRAF activated non-coding RNA is associated with poor prognosis for non-small cell lung cancer and promotes metastasis by affecting epithelialmesenchymal transition. Mol Cancer. 2014; 13:68.

314. Shi X, Sun M, Liu H, Yao Y, Kong R, Chen F, Song Y. A critical role for the long non-coding RNA GAS5 in proliferation and apoptosis in non-small-cell lung cancer. Mol Carcinog. 2013.

315. Han L, Kong R, Yin DD, Zhang EB, Xu TP, De W, Shu YQ. Low expression of long noncoding RNA GAS6-AS1 predicts a poor prognosis in patients with NSCLC. Med Oncol. 2013; 30(4):694.

316. Zhang L, Zhou XF, Pan GF, Zhao JP. Enhanced expression of long non-coding RNA ZXF1 promoted the invasion and metastasis in lung adenocarcinoma. Biomed Pharmacother. 2014.

317. Hou Z, Zhao W, Zhou J, Shen L, Zhan P, Xu C, Chang C, Bi H, Zou J, Yao X, Huang R, Yu L, Yan J. A long noncoding RNA Sox2ot regulates lung cancer cell proliferation and is a prognostic indicator of poor survival. Int J Biochem Cell Biol. 2014; 53: 380-8.

318. Luo J, Tang L, Zhang J, Ni J, Zhang HP, Zhang L, Xu JF, Zheng D. Long non-coding RNA CARLo-5 is a negative prognostic factor and exhibits tumor pro-oncogenic activity in non-small cell lung cancer. Tumour Biol. 2014. 